Article

\title{
Synthesis of New Proteomimetic Quinazolinone Alkaloids and Evaluation of Their Neuroprotective and Antitumor Effects
}

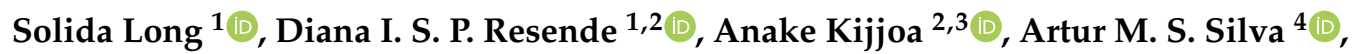 \\ Ricardo Fernandes ${ }^{5,6} \mathbb{D}_{\text {, }}$ Cristina P. R. Xavier ${ }^{5,6} \mathbb{D}^{\mathbb{D}}$, M. Helena Vasconcelos $5,6,7 \mathbb{D}$, \\ Emília Sousa ${ }^{1,2, * \mathbb{D}}$ and Madalena M. M. Pinto ${ }^{1,2} \mathbb{D}$ \\ 1 Laboratory of Organic and Pharmaceutical Chemistry (LQOF), Department of Chemical Sciences, \\ Faculty of Pharmacy, University of Porto, Rua de Jorge Viterbo Ferreira, 228, 4050-313 Porto, Portugal; \\ up201502099@ff.up.pt (S.L.); dresende@ff.up.pt (D.I.S.P.R.); madalena@ff.up.pt (M.M.M.P.) \\ 2 Interdisciplinary Centre of Marine and Environmental Research (CIIMAR), 4450-208 Matosinhos, Portugal; \\ ankijjoa@icbas.up.pt \\ 3 ICBAS-Instituto de Ciências Biomédicas Abel Salazar, University of Porto, 4050-313 Porto, Portugal \\ 4 Organic Chemistry and Natural Products Unit (QOPNA), Department of Chemistry, University of Aveiro, \\ 3810-193 Aveiro, Portugal; artur.silva@ua.pt \\ 5 Instituto de Investigação e Inovação em Saúde (i3S), University of Porto, 4200-135 Porto, Portugal; \\ ricardojorgefernandes@gmail.com (R.F.); cristinax@ipatimup.pt (C.P.R.X.); \\ hvasconcelos@ipatimup.pt (M.H.V.) \\ 6 Cancer Drug Resistance Group, Institute of Molecular Pathology and Immunology of the University of \\ Porto (IPATIMUP), 4200-135, Porto, Portugal \\ 7 Laboratory of Microbiology, Department of Biological Sciences, Faculty of Pharmacy, University of Porto, \\ 4050-313 Porto, Portugal \\ * Correspondence: esousa@ff.up.pt; Tel.: +351-2-2042-8689
}

Received: 8 January 2019; Accepted: 30 January 2019; Published: 1 February 2019

\begin{abstract}
New quinazolinone derivatives of the marine-derived alkaloids fiscalin B (3) and fumiquinazoline G (1), with neuroprotective and antitumor effects, were synthesized. Eleven quinazolinone-containing indole alkaloids were synthesized, proceeding the anti analogs via a one-pot method, and the syn analogs by the Mazurkiewicz-Ganesan approach. The neuroprotection capacity of these compounds on the rotenone-damage human neuroblastoma cell SH-SY5y was evaluated using the MTT assay. Compounds 1, 3, 5, and $\mathbf{7}$ showed more than $25 \%$ protection. The antitumor activity was investigated using the sulforhodamine $B$ assay and some compounds were tested on the non-malignant MCF-12A cells. Fumiquinazoline G (1) was the most potent compound, with $\mathrm{GI}_{50}$ values lower than $20 \mu \mathrm{M}$. Compounds 5, 7, and 11 were more active in all tumor cell lines when compared to their enantiomers. Compounds 5, 7, 10, and 11 had very little effect in the viability of the non-malignant cells. Differences between enantiomeric pairs were also noted as being essential for these activities the $S$-configuration at $\mathrm{C}-4$. These results reinforce the previously described activities of the fiscalin B (3) as substance P inhibitor and fumiquinazoline G (1) as antitumor agent showing potential as lead compounds for the development of drugs for treatment of neurodegenerative disorders and cancer, respectively.
\end{abstract}

Keywords: antitumor; neuroprotection; quinazolinones; fiscalin B; fumiquinazoline; enantioselectivity

\section{Introduction}

The pathophysiology of neurodegenerative diseases is poorly understood, and there are few therapeutic options, making neuroprotective drug discovery appealing for medicinal chemists. 
Although cancer and neurodegeneration have very distinct pathological disorders, over recent years growing evidence indicates that they share common molecular pathways [1]. Furthermore, it is recognized that several drugs used in the treatment of neurodegenerative diseases display antitumor effects while some antitumor drugs are neuroprotective [2].
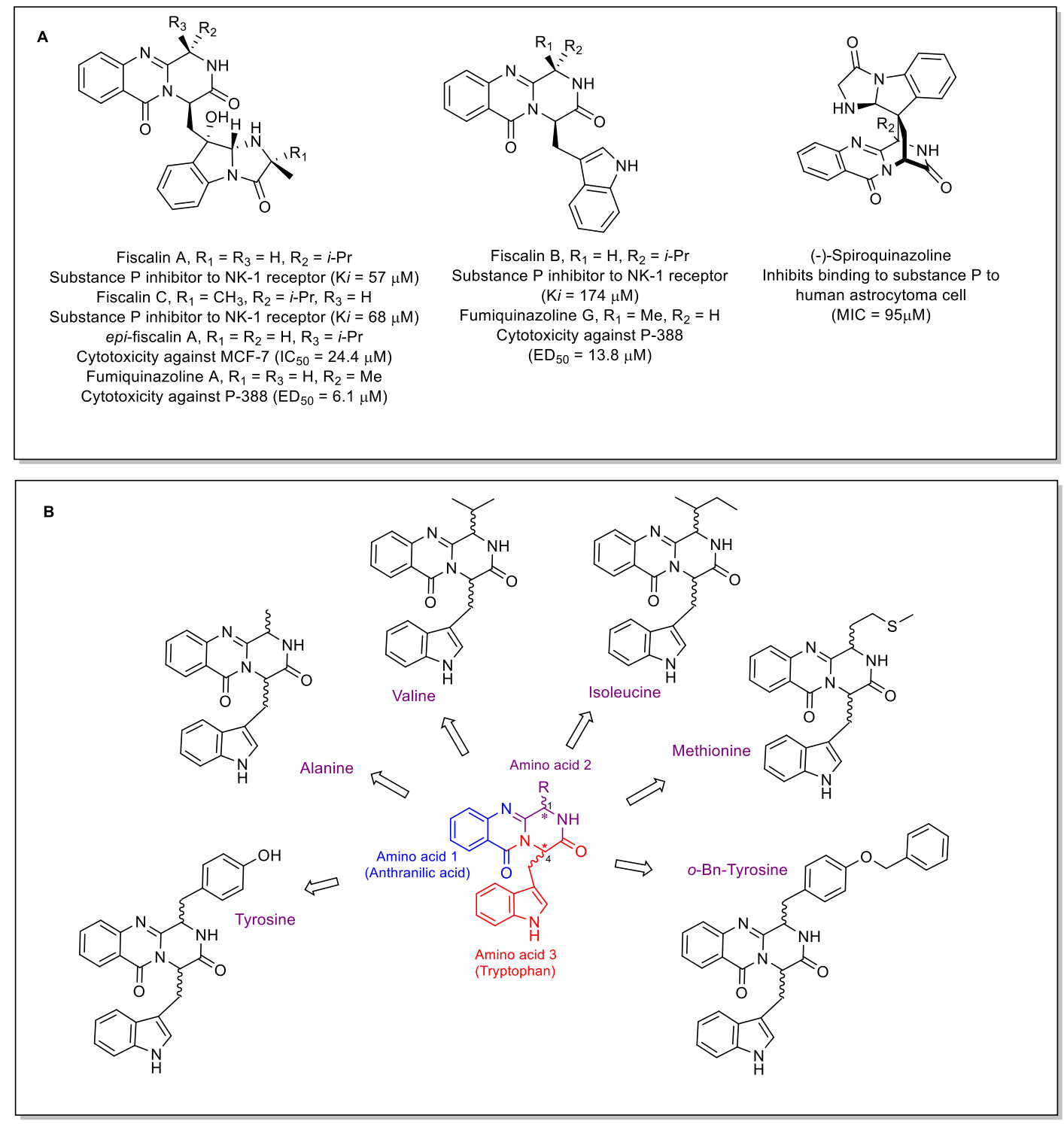

Figure 1. (A) Structure of natural quinazolinone-containing piperazine linked to an indole moiety such as substance P receptor antagonists and antitumor agents. (B) Proposed conformation constraint peptidomimetics synthetic quinazolinone alkaloids with different substituents at C-1.2.

Marine-derived indolylmethylpyrazinoquinazoline alkaloids, with a pyrazino[2,1-b]quinazoline3,6-dione linked to an indole moiety (Figure 1), have attracted our attention due to their promising antitumor activities [3], with epi-fiscalin A [4], fumiquinazoline A [5-9], fumiquinazoline G [7], and versiquinazolines [10] as the most active analogs. Moreover, the response of fiscalins A-C [11] and (-)-spiroquinazoline [12] (Figure 1A) as substance P inhibitors was also reported as a novel neuroprotective therapy in the intrastriatal 6-hydroxydopamine model of early stage of Parkinson's disease (PD) [13]. It is well known that among compounds implicated in neurodegeneration, non-proteinogenic amino acids may cause significant collateral neurodegenerative damage [14]. Rodgers et al. [15] reported that proteomimetic L-tyrosine of L-DOPA is cytotoxic in vitro and capable 
of generating protein aggregation, whereas non-protein amino acid $\beta$-methylamino-L-alanine (BMAA) has been linked to neurological diseases such as amyotrophic lateral sclerosis (ALS) and PD since BMAA was detected in brain protein of LAS and PD patients. In the previous work, we have described syntheses of a series of fiscalin B derivatives, which showed weak to moderate antitumor activity against non-small cell lung cancer (NCI-H460) and colorectal adenocarcinoma (HCT-15) cell lines [16]. These findings led us to develop a small library of proteomimetic quinazolinone-derived compounds (Figure 1B) with different configurations at C-1 and C-4 to investigate their action on neurodegenerative disorders as well as to further explore their potential as tumor cell growth inhibitors, putting in evidence the influence of the stereochemistry of the derivatives.

\section{Results}

\subsection{Chemistry}

Two synthetic approaches were used to prepare the syn and anti enantiomers of quinazolinone alkaloids. The syn enantiomers $\mathbf{1}$ (fumiquinazoline $\mathrm{G}$ ) and $\mathbf{2}$ were synthesized by the Mazurkiewicz-Ganesan procedure [17] (Scheme 1A) by coupling anthranilic acid (i) with D-tryptophan methyl ester (ii) for $\mathbf{1}$ or with L-tryptophan methyl ester (vi) for 2, using 1,1,3,3-tetramethylaminium tetrafluoroborate (TBTU) in alkaline condition to obtain the dipeptide iii or vii. Then, the coupling of iii or vii with $\mathrm{N}$-protected $\alpha$-amino acid chloride in a two-phase Schotten-Baumann condition yielded a tripeptide (dehydrate $\beta$-keto amides) $\mathbf{v}$ or ix. The oxazole intermediates were obtained by adding the dehydrating agent, triphenylphosphine $\left(\mathrm{Ph}_{3} \mathrm{P}\right)$, and $\mathrm{I}_{2}$ to dehydrate $\beta$-keto amide $\mathbf{v}$ or $\mathbf{i x}$, and N-deprotection by $20 \%$ piperidine afforded $\mathbf{1}$ and $\mathbf{2}$. On the other hand, a highly effective and environmentally friendly approach using a microwave-assisted multicomponent polycondensation of amino acids was used to prepare a series of the anti enantiomers of pyrazinoquinazoline alkaloids [18], as described in our previous work [16]. This methodology was used to synthesize new derivatives of fiscalin B (3) and fumiquinazoline G (1), 4, 5, 6, 7, and $\mathbf{8}$ (Scheme 1B). The syn isomer 9 was obtained along with 8 , and both were isolated by preparative thin layer chromatography (TLC). Diastereoisomers of $\mathbf{1 0}$ and $\mathbf{1 1}$ were obtained after deprotection of O-benzyl group from $\mathbf{8}$ and $\mathbf{9}$, respectively, using boron trichloride, according to Okaya et al. [19] with a slight modification. Compound 12 was also synthesized using microwave irradiation from 3,5-dichloroanthranilic acid (xiii). The purity of the compounds was determined by a reversed-phase liquid chromatography ( $\mathrm{LC}, \mathrm{C} 18, \mathrm{MeOH}: \mathrm{H}_{2} \mathrm{O}$; $60: 40$ or $\mathrm{CH}_{3} \mathrm{CN}: \mathrm{H}_{2} \mathrm{O} ; 50: 50$ ) and was found to be higher than $90 \%$. The enantiomeric ratio (er) was determined by a chiral LC equipped with amylose tris-3,5-dimethylphenylcarbamate column, using hexane:EtOH (80:20) or (70:30) as a mobile phase.

The reaction carried out using microwave with high temperature resulted not only in low yields of the products in the range of 2.2 to $21.7 \%$, but also with a high degree of epimerization (Scheme 1). Contrary to what has been found in our previous study [16] that the reaction under a microwave irradiation was regioselective and yielded only anti isomers, the synthesis of 8 , by a microwave irradiation, produced also its syn epimer, 9 [4-(benzyloxy)-1-methylbenzyl at C-1], with a 22\% yield. This study suggested that microwave irradiation is beneficial for the synthesis of quinazolinone alkaloids with bulky substituents at C-1 which was previously reported as unsuccessful by Mazurkiewicz-Ganesan method [17]. However, this methodology failed for the synthesis of syn enantiomers as described in the experimental section for $\mathbf{4}$ and $\mathbf{6}$. The syn enantiomers of $\mathbf{1}$ and $\mathbf{2}$ were synthesized by Mazurkiewicz-Ganesan approach [17] and gave moderate yields ( 37 and 26\%, respectively). Compounds $\mathbf{1 0}$ and $\mathbf{1 1}$ were obtained by deprotection in good yields (30 and $69 \%$, respectively).

Moreover, the methodology involving microwave irradiation was characterized by producing partial epimerizations. Surprisingly, 4 and 5 , with three stereogenic centers, gave a higher enantiomeric ratio (er) of $99 \%$. Similar to the previous report for fiscalin B analogs [16], the multi-step approach gave a better yield and, in most cases, higher enantiomeric ratios due to milder conditions; nonetheless, the one-pot reaction is a faster alternative to provide anti enantiomers with diversity of substituents at C-1. 


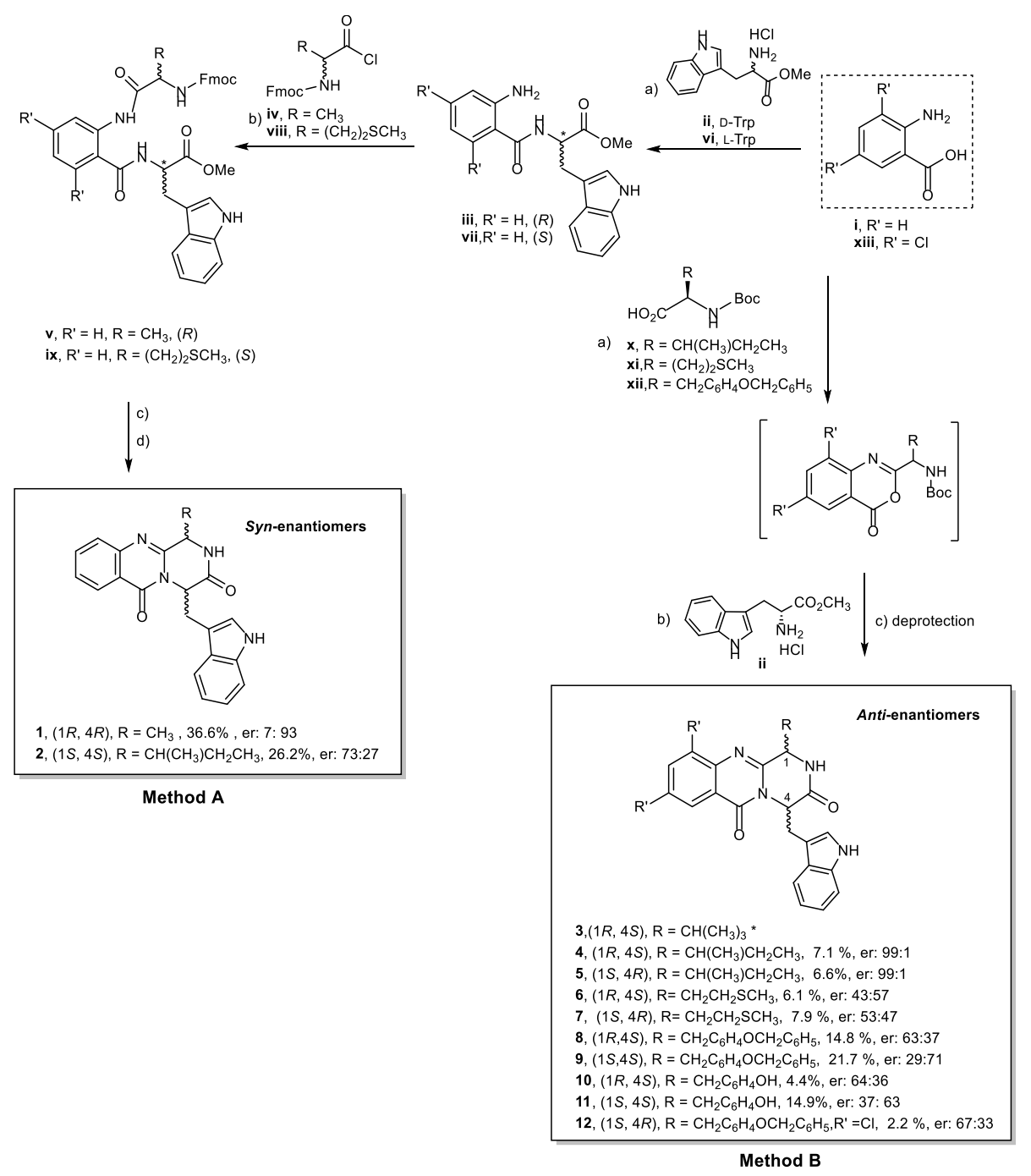

Scheme 1. (A) Mazurkiewicz-Ganesan approach for 1 and 2. Reagents and conditions (a) $\mathrm{CH}_{3} \mathrm{CN}$, TBTU, Et ${ }_{3} \mathrm{~N}$, rt, 5 h; (b) $\mathrm{CH}_{2} \mathrm{Cl}_{2}$ /aq. $\mathrm{Na}_{2} \mathrm{CO}_{3}, \mathrm{rt}, 3$ h; (c) dried $\mathrm{CH}_{2} \mathrm{Cl}_{2}, \mathrm{Ph}_{3} \mathrm{P}, \mathrm{I}_{2}, \mathrm{EtN}(\mathrm{i}-\mathrm{Pr})_{2}, \mathrm{rt}$, overnight; (d) piperidine in $\mathrm{CH}_{2} \mathrm{CH}_{2}, \mathrm{rt}, 12 \mathrm{~min}$, then $\mathrm{CH}_{3} \mathrm{CN}$, DMAP, reflux $19 \mathrm{~h}$. Fmoc = fluorenylmethyloxycarbonyl; DMAP = 4-(dimethylamino)pyridine, TBTU = 1,1,3,3-tetramethylaminium tetrafluoroborate. (B) One-pot synthesis of pyrazinoquinazolinone alkaloids 3, 4, 5, 6, 7, 8, 9, 10, 11, and 12. Reagents and conditions: (a) dried pyridine, $(\mathrm{PhO})_{3} \mathrm{P}, 55^{\circ} \mathrm{C}, 16-24 \mathrm{~h} ;(\mathbf{b})$ dried pyridine, $(\mathrm{PhO})_{3} \mathrm{P}, 220^{\circ} \mathrm{C}$, $1.5 \mathrm{~min}$; (c) $\mathrm{BCl}_{3}, \mathrm{CH}_{2} \mathrm{Cl}_{2},-78^{\circ} \mathrm{C}$ for $10 \mathrm{~min}$ then $25^{\circ} \mathrm{C}$ for $6 \mathrm{~h}$; $\mathrm{Boc}=$ tert-butyloxycarbonyl, $\mathrm{R}^{\prime}=\mathrm{H}$ when no mentioned; $\mathrm{er}=$ enantiomeric ratio calculated from the peak area from chiral LC experiments (by using equation $X \times 100 / X n$ in which $X$ is the peak area of each peak and $X n$ is the total peak area. ${ }^{*}$ referred to previous work [16].

\subsection{Structure Elucidation}

A series of 1D and 2D NMR experiments and HRMS were used to confirm the structures of all the new compounds (Supplementary information, Figures S1-S57). The amide proton (H-2) appeared as a broad singlet (brs) in the anti isomers, i.e., $\mathbf{4}, \mathbf{5}, \mathbf{6}, \mathbf{7}, \mathbf{8}, \mathbf{1 0}$, and $\mathbf{1 2}$, but as a doublet $(d)$ in the syn isomers, i.e., 1, 2, 9, and 11 (Supplementary information, Figures S1-S21). Each stereoisomer exhibited different chemical shift values for H-2, H-4, and H-1. For example, for isomers 2, 4, and 5, with the isobutyl group at C-1, the syn and the anti isomers were distinguished by the chemical shift values of $\mathrm{H}-1$ and H-1'; which were $c a . \delta_{\mathrm{H}} 4.03$ and 0.93 , respectively for the syn isomer (2), and at $c a . \delta_{\mathrm{H}} 2.80$ and 2.3, respectively, for the anti isomers (4 and 5), due to the absence of the shielding effect by the aromatic ring of the indole moiety [20]. 
This assignment was also confirmed by HMBC correlations which distinguished between the isomers of $\mathbf{2}, \mathbf{4}$, and 5 by the presence or absence of correlations from H-2 to C-3, C-4, and C-14. In 2, H-2 showed no correlation to C-3, C-4, and C-14 whereas in 4 and 5, H-2 showed correlations to those three carbons. H-4 also showed correlations to different carbons among isomers. $\mathrm{H}-4$ showed correlations to C-3 and C-4' in 2, but to C-3, C-14, C-4', and C-5' in 4, while there were no such correlations observed in 5 . H-1 of the syn isomer of 2 showed correlation only to C-14 while in the anti isomer of 4 and 5, it displayed correlations to C-14, C-1' and C-3" (Figure 2). In contrast, in 1, H-2 and H-4 showed no correlations to carbons that are two or three bonds away $\left({ }^{2} J\right.$ or $\left.{ }^{3} J\right)$, and $\mathrm{H}-1$ showed cross peaks to C-3 and C-14. Furthermore, H-8 and H-10 of 12 (with $\mathrm{Cl}$ at C-9 and C-11) appeared as two doublets $\left(\delta_{\mathrm{H}} 8.26, J=2.4 \mathrm{~Hz}\right.$ and $\delta_{\mathrm{H}} 7.85, J=2.4 \mathrm{~Hz}$, respectively) while in other compounds H-8 appeared as a double doublet and H-10 as double-double doublet. The NOESY spectrum for compound 6 with an anti configuration $(1 R, 4 S)$ showed correlations from $\mathrm{H}-1$ to $\mathrm{H}-\mathrm{1}^{\prime}$ and $\mathrm{H}-3^{\prime}$ (methyl group attached to $\mathrm{S}$ atom) and H-2, while H-4 showed cross peak to H-4' (Supplementary information, Figure S56). The NOESY spectrum for the syn configuration compound 2 (1S, 4S) exhibited correlations between H-1 and H-1', H-2', H-3", and H-2 as well as from H-4 to H-4'. Also, correlations between H-4' and H-1' in the syn configuration compound 2 could be noted while these was absent in the anti configuration compound $\mathbf{6}$ (Supplementary information, Figure S57). These observations were similar to the previously described for fiscalin B isomers [16].

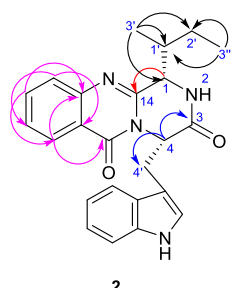

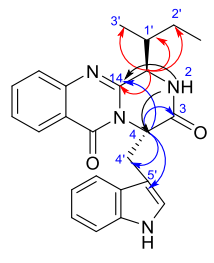

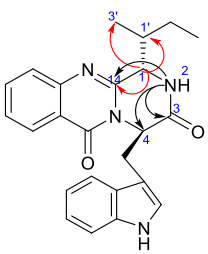

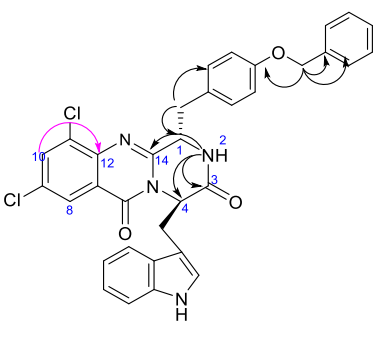

12

Figure 2. Key HMBC correlations for 2, 4, 5, and 12.

\subsection{Neuroprotection Activity}

The neuroprotection assay was performed on human neuroblastoma cell SH-SY5y treated with rotenone, a toxin that acts by interfering with the electron transport chain in mitochondria, inhibiting the transfer of electron from iron-sulfur centers in complex I to ubiquinone. This in turn interferes with NADH, therefore creating reactive oxygen species (ROS), which can damage DNA and other components, leading to cell death [21,22]. In animal experimentation, rotenone reproduces features of PD, including selective nigrostriatal dopaminergic degeneration and alpha-synuclein-positive cytoplasmic inclusions [23]. Furthermore, rotenone triggers mitochondrial impairment, oxidative damage, and cell death in neuronal culture, phenomena that are common in neurodegenerative diseases [24].

In this assay, the SH-SY5y cells were treated with $2 \mu \mathrm{M}$ of rotenone for $24 \mathrm{~h}$. The MTT assay, which assesses cell metabolic activity through the activity of $\mathrm{NAD}(\mathrm{P}) \mathrm{H}$-dependent cellular oxidoreductase enzyme that reflect the number of viable cells [24], was used for quantifying the cell death. The cellular protection of $\mathbf{1}, \mathbf{2}, 4,5,6,7,8,9, \mathbf{1 0}, \mathbf{1 1}$, and 12 against the toxin was determined by MTT assay and expressed as percentage referred to the cell treated with rotenone at 10 different concentrations to produce the dose-dependent curve. Synthetic fiscalin B (3), previously obtained by some of us [16] and was reported as a substance P antagonist [12], was also tested in this assay for comparison. Compounds considered as neuroprotective must have (i) more than $25 \%$ of protection, (ii) statistically significant difference, and (iii) protection is more than one dose [23,24].

Most of the compounds, at the highest concentration tested $(100 \mu \mathrm{M})$, were found to increase toxicity, which ensures that the compounds were assayed at their maximal tolerated dose (MTD). Compounds 1, 2, 3, 4, 5, 10, 11, and 12 showed high toxicity at $100 \mu \mathrm{M}$ and some of them also at 
$50 \mu \mathrm{M}$. The compounds which showed neuroprotective activity in rotenone-treated in vitro model were 1, 3, 5, and 7. Additionally, some neuroprotective effect was also observed for 11 while 2, 4, 6, 8, 9, 10, and 12 did not display any neuroprotection (Figure 3). Compound 1, 3, 5, and 7 showed more than $25 \%$ of protection of the cell death at least in one concentration. Compound 7 exhibited the best neuroprotective activity, with rotenone inhibitory of $47,40,42,39$, and $31 \%$ at the concentrations of $1.56,3.13,6.25,12.5$, and $25 \mu \mathrm{M}$, respectively.
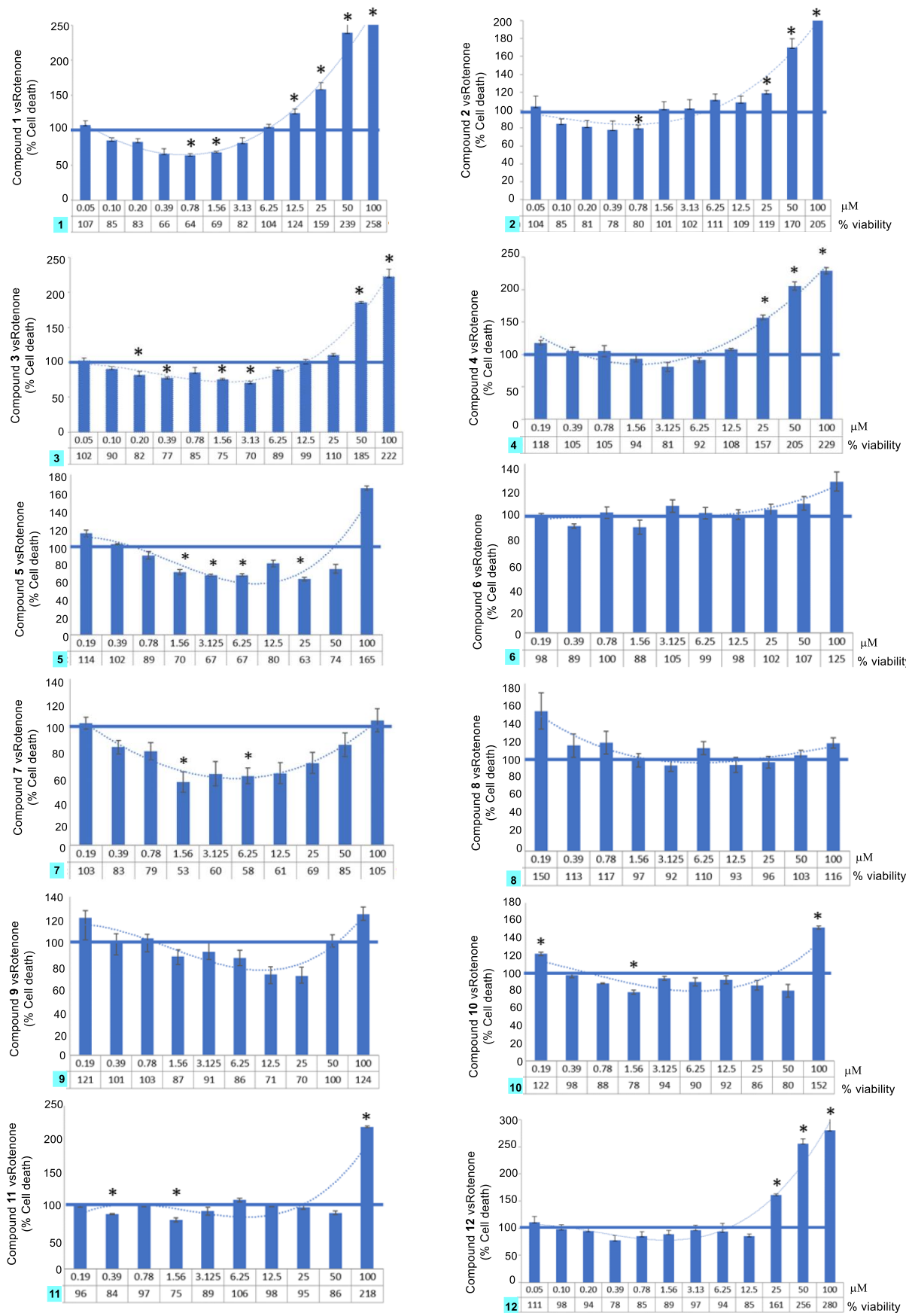

Figure 3. Neuroprotective effect of 1-12 against rotenone-induced neuron cell death. Neuroblastoma cells were treated with $2 \mu \mathrm{M}$ rotenone to induce cell injury. Compounds were assayed at several concentrations $(0.1$ to $100 \mu \mathrm{M})$ for $24 \mathrm{~h}$. Cell death was determined using MTT test. The data represent the percentage of rotenone-induced cell death (means and errors), performed in triplicate. Statistically significance of differences from rotenone-treated cells was examined with the Student's t-test $\left({ }^{*} p<0.05\right)$. 


\subsection{Tumor Cell Growth Inhibitory Activity}

Compounds 1-2, 4-8, 10 and 11 were tested for tumor cell growth inhibitory activity on three human tumor cell lines: NCI-H460 (non-small cell lung cancer), BxPC3 (human pancreatic adenocarcinoma), and PANC1 (human pancreatic adenocarcinoma) using the sulforhodamine B (SRB) colorimetric assay $[16,25]$. Cells were exposed to five concentrations of each compound (at a maximum concentration of 25,150 or $200 \mu \mathrm{M}$, depending on the compound) for $48 \mathrm{~h}$. Doxorubicin was used as a positive control for NCI-H460 cell line, and gemcitabine was used as a positive control for the BxPC3 and PANC1 cell lines. The antitumor activity was reported as GI $_{50}$ concentration (drug concentration that inhibits the growth of cancer cells by $50 \%$ ).

Compounds 2, 4-8, 10, and 11 showed weak to moderate growth inhibitory, with GI $_{50}$ ranking from $27.93 \pm 0.8$ to $151.07 \pm 2.9 \mu \mathrm{M}$ (Table 1). In general, compounds with the indolylmethyl substituent on C-4 whose configuration of C-4 is $R$ showed better antitumor activity in all cell lines when compared to those with $4 S$ configuration. This was evidenced by stronger antitumor activities of $\mathbf{1}, 5$, and 7 than those of 2, 4, and 6 . Only fumiquinazoline $G$ (1) with $R$-configuration for both C-1 and C-4 showed strong growth inhibitory effect in all cancer cell lines tested (GI ${ }_{50}$ ranging from $7.62 \pm 0.7$ to $17.34 \pm 1.7 \mu \mathrm{M})$. In addition, these results agree with those reported in our previous publication in which enantiomers with $R$-configuration at C-1 and C-4 showed better antitumor activity than enantiomers with $S$-configuration [16]. Unfortunately, $\mathbf{9}$ and $\mathbf{1 2}$ tested in this study could not be evaluated regarding their tumor cell growth inhibitory activity due to contamination of the compounds (data not shown).

Table 1. Growth inhibition $\left(\mathrm{GI}_{50}\right)$ concentration of $\mathbf{1 - 2 , 4 - 8 , 1 0}$, and 11 against NCI-H460, BxPC3, and PANC1 human tumor cell lines.

\begin{tabular}{cccc}
\hline \multirow{2}{*}{ Compounds } & \multicolumn{3}{c}{ GI $_{\mathbf{5 0}}(\boldsymbol{\mu M})$} \\
\cline { 2 - 4 } & NCI-H460 & BxPC3 & PANC1 \\
\hline $\mathbf{1}$ & $7.62 \pm 0.7$ & $17.34 \pm 1.7$ & $10.06 \pm 0.8$ \\
$\mathbf{2}$ & $65.38 \pm 4.0$ & $104.77 \pm 10.9$ & $86.30 \pm 11.1$ \\
$\mathbf{4}$ & $69.26 \pm 2.9$ & $88.81 \pm 9.6$ & $78.17 \pm 8.4$ \\
$\mathbf{5}$ & $40.11 \pm 5.0$ & $57.44 \pm 4.7$ & $60.68 \pm 4.8$ \\
$\mathbf{6}$ & $151.07 \pm 2.9$ & $126.06 \pm 21.5$ & $112.44 \pm 12.7$ \\
$\mathbf{7}$ & $61.37 \pm 2.3$ & $99.10 \pm 5.8$ & $76.65 \pm 4.8$ \\
$\mathbf{8}$ & $72.68 \pm 6.2$ & $115.42 \pm 12.1$ & $74.90 \pm 7.2$ \\
$\mathbf{1 0}$ & $38.00 \pm 1.5$ & $50.59 \pm 2.3$ & $34.13 \pm 1.8$ \\
$\mathbf{1 1}$ & $46.25 \pm 5.8$ & $29.87 \pm 3.7$ & $27.93 \pm 0.8$ \\
Gemcitabine & - & $0.20 \pm 0.08$ & $0.73 \pm 0.22$ \\
Doxorubicin & $0.0124 \pm 0.0018$ & - & -
\end{tabular}

The $\mathrm{GI}_{50}$ concentrations $(\mu \mathrm{M})$ were determined by the SRB assay and results are the mean of \pm SEM of three independent experiments. Gemcitabine was use as a positive control for the BxPC3 and PANC1 cell lines, and doxorubicin as a positive control for the NCI-H460 cell line. (-) indicates not-determined.

\subsection{Activity in Non-Tumor Cells}

Compounds presenting the best neuroprotection and/or antitumor effects, namely 5, 7, 10, and 11, were also evaluated against the non-malignant MCF-12A human breast epithelial cells. For that, one concentration of each compound (corresponding to approximately the highest $\mathrm{GI}_{50}$ value obtained in the cell growth inhibitory activity assay) was tested and the percentage of cell growth inhibition was determined by the SRB assay. In this assay, the duration of the SRB assay had to be longer since non-malignant cells have a much slower growth rate than tumor cells. This longer duration of the assay also allowed to evaluate possible delayed effects of the compounds in these non-malignant cells. Therefore, the assay in the MCF-12A cells was performed following 7 days of treatment with compounds ( $48 \mathrm{~h}$ with compound incubation plus 5 days without the compounds). As shown in Table 2, all the tested compounds caused a small effect in the growth of these non-malignant cells, 
meaning that the cell growth inhibition detected in MCF-12A cells after 7 days of treatment was much lower than that detected in the tumor cell lines after 2 days of treatment (when tested at the same concentration).

Table 2. The percentage of cell growth inhibition (relative to the control) of 5, 7, 10, and 11 in the non-malignant MCF-12A human breast epithelial cells.

\begin{tabular}{ccc}
\hline Compounds & Concentration $(\boldsymbol{\mu M}) *$ & $\begin{array}{c}\text { \% Cell Growth Inhibition } \\
\text { (Relative to the Control) }\end{array}$ \\
\hline $\mathbf{5}$ & 65 & $71.69 \pm 7.9$ \\
$\mathbf{7}$ & 100 & $89.56 \pm 3.7$ \\
$\mathbf{1 0}$ & 50 & $75.63 \pm 4.7$ \\
$\mathbf{1 1}$ & 50 & $71.15 \pm 2.0$ \\
\hline
\end{tabular}

* These concentrations correspond to approximately the highest $\mathrm{GI}_{50}$ concentrations determined in the tumor cell lines tested (from Table 1). The values were determined by the SRB assay and results are the mean of \pm SEM of three independent experiments.

\section{Structural-Activity Relationship (SAR)}

Structure-activity relationship analysis showed that the obtained results were consistent with data previously reported for the natural product fumiquinazoline G [26] and fiscalin B [11,27-29] and their derivatives [16] (Figure 4). Moreover, it was found that the configurations of C-1 and C-4 have strong influence on antitumor activity since fumiquinazoline $\mathrm{G}(\mathbf{1})$, with $R$-configurations at C-1 and C-4, showed the strongest antitumor effect against NCI-H460, BxPC3, and PANC1 cell lines. Comparing the enantiomeric pairs 4 and 5, compound 5 with also R-configuration at $C-4$ and $S$ at $C-1$ showed stronger antitumor effect. In contrast, their isomer, compound 2, with S-configurations both at C-1 and C-4 were $S$ exhibited the weakest inhibitory effect on all cell lines. In addition, the substituent at C-1 also affected the antitumor activity. Alkyl residues (isoleucine residues) in 2, 4, and 5 showed better antitumor activity than that found in compounds with a sulfur atom (methionine residues) such as 6 and 7. Aromatic groups such as the tyrosine residue present in $\mathbf{1 0}$ and $\mathbf{1 1}$ produced good antitumor activity, with $\mathrm{GI}_{50}$ values ranging from $27.93 \pm 0.8$ to $50.59 \pm 2.3 \mu \mathrm{M}$, but the substitution by benzyl groups as in the case of $\mathbf{8}$ caused a 2-fold decrease in the antitumor activity. Regarding neuroprotection capacity, SAR suggests that the $R$-configuration at $C-4$ is also important (when comparing compounds 6 and 7, Figure 3); however, increasing the molecular weight of C-1 substituent has a negative effect in neuroprotection. In addition, this study confirmed that quinazolinone alkaloids which act as substance P inhibitors (i.e., fiscalin B, 3), showed a potential as neuroprotective agents. Therefore, the studied fumiquinazoline-derived alkaloids showed promising antitumor and neuroprotection effects and deserves to be further explored.
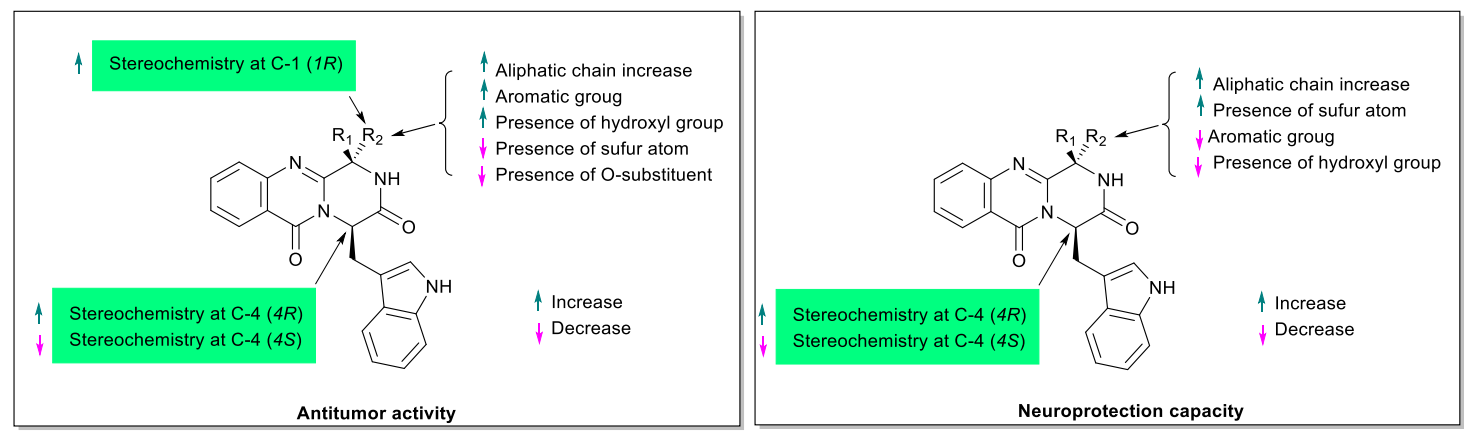

Figure 4. Structure-activity relationship studies of quinazolinone alkaloids 1-12 with antitumor and neuroprotective activities. 


\section{Materials and Methods}

\subsection{General Procedure}

All reagents were from analytical grade. Dried pyridine and triphenylphosphite were purchased from Sigma (Sigma-Aldrich Co. Ltd., Gillingham, UK). Anthranilic acid (i) and Protected amino acids (ii and vii) were purchased from TCI (Tokyo Chemical Industry Co. Ltd., Chuo-ku, Tokyo, Japan). Column chromatography purifications were performed using flash silica Merck 60, 230-400 mesh (EMD Millipore corporation, Billerica, MA, USA) and preparative TLC was carried out on precoated plates Merck Kieselgel $60 \mathrm{~F}_{254}$ (EMD Millipore corporation, Billerica, MA, USA), spots were visualized with UV light (Vilber Lourmat, Marne-la-Vallée, France). Melting points were measured in a Köfler microscope and are uncorrected. Infrared spectra were recorded in a $\mathrm{KBr}$ microplate in a FTIR spectrometer Nicolet iS10 from Thermo Scientific (Waltham, MA, USA) with Smart OMNI-Transmission accessory (Software 188 OMNIC 8.3, Thermo Fisher Scientific Inc., Austin, TX, USA). ${ }^{1} \mathrm{H}$ and ${ }^{13} \mathrm{C}$ NMR spectra were recorded in $\mathrm{CDCl}_{3}$ or $\mathrm{DMSO}_{-} \mathrm{d}_{6}$ (Deutero $\mathrm{GmbH}$, Kastellaun, Germany) at room temperature unless otherwise mentioned on Bruker AMC instrument (Bruker Biosciences Corporation, Billerica, MA, USA), operating at $300 \mathrm{MHz}$ for ${ }^{1} \mathrm{H}$ and $75 \mathrm{MHz}$ for ${ }^{13} \mathrm{C}$ ). Carbons were assigned according to HSQC and or HMBC experiments. Optical rotation was measured at $25^{\circ} \mathrm{C}$ using the ADP 410 polarimeter (Bellingham + Stanley Ltd., Royal Tunbridge Wells, Kent, UK), using the emission wavelength of sodium lamp, concentrations are given in g/100 mL. Qualitative GC-MS analyses were performed on a Trace GC 2000 Series ThermoQuest gas chromatography (Thermo Fisher Scientific Inc., Austin, TX, USA) equipped with ion-trap GCQ Plus ThermoQuest Finnigan mass detector (Thermo Fisher Scientific Inc.). Chromatographic separation was achieved using a capillary column (30 $\mathrm{m} \times 0.25 \mathrm{~mm} \times 0.25 \mu \mathrm{m}$, cross-linked 5\% diphenyl and 95\% dimethyl polysiloxane) from Thermo Scientific ${ }^{\mathrm{TM}}$ (Thermo Fisher Scientific Inc.) and high-purity helium C-60 as carrier gas. High resolution mass spectra (HRMS) were measured on a Bruker FTMS APEX III mass spectrometer (Bruker Corporation, Billerica, MA, USA) recorded as ESI (Electrospray) made in Centro de Apoio Cientifico e Tecnolóxico á Investigation (CACTI, University of Vigo, Pontevendra, Spain). The purity of synthesized compounds was determined by reversed-phase LC with diode array detector (DAD) using C18 column (Kimetex ${ }^{\circledR}$, 2.6 EV0 C18 $100 \AA$, $\left.150 \times 4.6 \mathrm{~mm}\right)$, and the mobile phase was methanol:water $(60: 40)$ or acetonitrile:water (50:50). Enantiomeric ratio was determined by chiral LC (LCMS-2010EV, Shimadzu, Lisbon, Portugal), employing a system equipped with a chiral column (Lux ${ }^{\circledR} 5 \mu m$ Amylose-1, $250 \times 4.6 \mathrm{~mm})$ and UV-detection at $254 \mathrm{~nm}$, mobile phase was hexane:ethanol (80:20) and the flow rate was $0.5 \mathrm{~mL} / \mathrm{min}$. Compound 3 was obtained according to previous described method [17]. Neuroprotection studies were performed in Fundación Centro de Excelencia en Investigación de Medicamentos Innovadores en Andalucía, MEDINA (Granada, Spain).

4.2. General Conditions for the Synthesis of Compound $(1 R, 4 R)-4-((1 H$-indol-3-yl)methyl)-1-((R)-methyl)-1,2dihydro-6H-pyrazino[2,1-b]quinazoline-3,6(4H)-dione (1)

To a mixture of anthranilic acid (i, $287 \mathrm{mg}, 2.39 \mathrm{mmol}$ ) and TBTU (920 mg, $2.86 \mathrm{mmol}, 1.2 \mathrm{equiv})$ in acetonitrile $(20 \mathrm{~mL})$ was added $\mathrm{Et}_{3} \mathrm{~N}(833 \mu \mathrm{L}, 4.78 \mathrm{mmol}, 2$ equiv) and D-tryptophan methyl ester (ii, $521 \mathrm{mg}, 2.39 \mathrm{mmol}$ ) at room temperature. After stirring for $5 \mathrm{~h}$, the reaction mixture was concentrated under reduced pressure. The residue was dissolved in $\mathrm{CH}_{2} \mathrm{Cl}_{2}$ and washed with $1 \mathrm{M}$ $\mathrm{HCl}$, extracted with $\mathrm{CH}_{2} \mathrm{Cl}_{2}(3 \times 100 \mathrm{~mL})$, dried with $\mathrm{Na}_{2} \mathrm{SO}_{4}$, filtered, and concentrated. The residue was purified by flash chromatography (eluent $1 \% \mathrm{MeOH}$ in $\mathrm{CH}_{2} \mathrm{Cl}_{2}$ ) to yield iii as a white solid. ${ }^{1} \mathrm{H}$ NMR and ${ }^{13} \mathrm{C}$ NMR referred to the previous work [16]. To a solution of iii (140 $\left.\mathrm{mg}, 0.416 \mathrm{mmol}\right)$ in dried $\mathrm{CH}_{2} \mathrm{Cl}_{2}(10 \mathrm{~mL}) \mathrm{N}$-Fmoc-D-alanine-Cl [30] (iv,182 mg, $\left.0.5 \mathrm{mmol}\right)$ was added. The mixture was stirred for $30 \mathrm{~min}$, followed by the addition of aqueous $\mathrm{Na}_{2} \mathrm{CO}_{3}(1 \mathrm{M}, 8 \mathrm{~mL}, 8 \mathrm{mmol})$. After continuous stirring for $3 \mathrm{~h}$, the mixture was extracted with $\mathrm{CH}_{2} \mathrm{Cl}_{2}(4 \times 100 \mathrm{~mL})$, dried with $\mathrm{Na}_{2} \mathrm{SO}_{4}$, filtered, and concentrated. The residue was purified by flash chromatography (eluent: $5 \% \mathrm{MeOH}$ in $\mathrm{CH}_{2} \mathrm{Cl}_{2}$ ) to give $\mathbf{v}(220.4 \mathrm{mg}, 84.2 \%)$ as a white solid. ${ }^{1} \mathrm{H} \mathrm{NMR}\left(300 \mathrm{MHz}, \mathrm{CDCl}_{3}\right) \delta 11.48(\mathrm{~s}, 1 \mathrm{H}), 8.58(\mathrm{~d}, 1 \mathrm{H}$, 
$J=8.4 \mathrm{~Hz}), 8.13(\mathrm{~s}, 1 \mathrm{H}), 7.76(\mathrm{~d}, 2 \mathrm{H}, J=7.5 \mathrm{~Hz}), 7.66(\mathrm{~d}, 1 \mathrm{H}, J=7.1 \mathrm{~Hz}), 7.59(\mathrm{t}, 1 \mathrm{H}, J=7.4 \mathrm{~Hz}), 7.49-7.26$ $(\mathrm{m}, 8 \mathrm{H}), 7.17(\mathrm{t}, 1 \mathrm{H}, J=7.2 \mathrm{~Hz}), 7.06(\mathrm{t}, 1 \mathrm{H}, J=7.6 \mathrm{~Hz}), 7.00(\mathrm{t}, 1 \mathrm{H}, J=7.7 \mathrm{~Hz}), 6.97(\mathrm{~s}, 1 \mathrm{H}), 6.71(\mathrm{~d}$, $1 \mathrm{H}, J=7.6 \mathrm{~Hz}), 5.55(\mathrm{~d}, 1 \mathrm{H}, J=6.8), 5.03(\mathrm{dt}, 1 \mathrm{H}, J=7.6,5.3 \mathrm{~Hz}), 4.44(\mathrm{~m}, 2 \mathrm{H}), 4.36(1 \mathrm{~m}, 1 \mathrm{H}), 4.26(\mathrm{t}$, $1 \mathrm{H}, J=7.0 \mathrm{~Hz}), 3.73(\mathrm{~s}, 3 \mathrm{H}), 3.40(\mathrm{dd}, 1 \mathrm{H}, J=15.3,5.8 \mathrm{~Hz}), 3.34(\mathrm{dd}, 1 \mathrm{H}, J=15.3,5.3 \mathrm{~Hz}), 1.53(\mathrm{~d}, 3 \mathrm{H}$, $J=7.0 \mathrm{~Hz})$ and ${ }^{13} \mathrm{C} \mathrm{NMR}\left(75 \mathrm{MHz}, \mathrm{CDCl}_{3}\right) 172.7,172.2,168.8,156.6,144.2,143.8,141.4,138.6,136.4$, $132.8,127.8,127.4,127.2,125.3,123.4,123.3,122.1,121.6,120.9,120.0,119.5,118.3,111.7,109.2,67.3,53.6$, $52.7,52.2,47.3,27.3,18.4$ (See in [31]). To a solution of $\mathbf{v}(183.2 \mathrm{mg}, 0.278 \mathrm{mmol})$ in dried $\mathrm{CH}_{2} \mathrm{Cl}_{2}(20 \mathrm{~mL})$ $\mathrm{Ph}_{3} \mathrm{P}$ (365 mg, $1.39 \mathrm{mmol}, 5$ equiv), $\mathrm{I}_{2}$ (345 mg, $1.36 \mathrm{mmol}$. 4.9 equiv), and $N, N$-diisopropylethylamine ( $489 \mu \mathrm{L}, 2.81 \mathrm{mmol}, 10$ equiv) were added. The reaction mixture was stirred at room temperature for $5 \mathrm{~h}$, quenched with aqueous $\mathrm{Na}_{2} \mathrm{CO}_{3}$, and extracted with $\mathrm{CH}_{2} \mathrm{Cl}_{2}(3 \times 100 \mathrm{~mL})$, dried with $\mathrm{Na}_{2} \mathrm{SO}_{4}$, filtered, and concentrated. Hexane was added to remove an excess of $\mathrm{Ph}_{3} \mathrm{P}$, the precipitate was filtered and was treated with $\mathrm{CH}_{2} \mathrm{Cl}_{2}(10 \mathrm{~mL})$ and piperidine $(2.5 \mathrm{~mL}, 20 \%)$ at room temperature for $20 \mathrm{~min}$, followed by solvent evaporation to provide the solid which was triturated with hexane $(1 \times 200 \mathrm{~mL}), \mathrm{CH}_{2} \mathrm{Cl}_{2} / \mathrm{PhMe}(1 \times 200 \mathrm{~mL})$, and hexane $(1 \times 200 \mathrm{~mL})$. The vacuum-dried crude residue was dissolved in $\mathrm{CH}_{3} \mathrm{CN}(10 \mathrm{~mL})$ in the presence of DMAP $(64 \mathrm{mg}, 0.53 \mathrm{mmol})$ and refluxed for $19 \mathrm{~h}$. The reaction mixture was purified by preparative TLC (EtOAc:MeOH: $\mathrm{CH}_{2} \mathrm{Cl}_{2}, 50: 2.5: 47.5$ ) to afford $\mathbf{1}$. Yield: $22.4 \mathrm{mg}$, 21.11\%; $\mathrm{er}=7: 93$; $\mathrm{mp}: 105.9-106.5^{\circ} \mathrm{C} ;[\alpha]_{D}^{30}=-117.64\left(c 0.034 ; \mathrm{CHCl}_{3}\right) ; v_{\max }(\mathrm{KBr}) 3406$, 2924, 2852, 1678, 1473, 1329, and $1261 \mathrm{~cm}^{-1} ;{ }^{1} \mathrm{H} \mathrm{NMR}\left(300 \mathrm{MHz}, \mathrm{CDCl}_{3}\right): \delta 8.38(\mathrm{dd}, 1 \mathrm{H}, J=8.0$ and $1.1 \mathrm{~Hz}, \mathrm{CH}), 8.18(\mathrm{br}, 1 \mathrm{H}, \mathrm{NH}-\operatorname{Tr} \mathrm{p}), 7.78(\mathrm{ddd}, 1 \mathrm{H}, J=8.5,7.1$, and $1.6 \mathrm{~Hz}, \mathrm{CH}), 7.57(\mathrm{~d}, 1 \mathrm{H}, J 7.4 \mathrm{~Hz}$, $\mathrm{CH}), 7.54(\mathrm{dd}, 1 \mathrm{H}, J=8.0$ and $1.0 \mathrm{~Hz}, \mathrm{CH}), 7.29(\mathrm{~d}, 1 \mathrm{H}, J=3.1 \mathrm{~Hz}, \mathrm{CH}-\operatorname{Trp}), 7.27(\mathrm{~d}, 1 \mathrm{H}, J=2.0 \mathrm{~Hz}$, CH-Trp), 7.08 (ddd, $1 \mathrm{H}, J=9.5,7.0$ and $0.9 \mathrm{~Hz}, \mathrm{CH}-\mathrm{Trp}$ ), 6.83 (ddd, $1 \mathrm{H}, J=8.7,7.1$ and $1.0 \mathrm{~Hz}, \mathrm{CH}-\operatorname{Trp}$ ), $6.73(\mathrm{~d}, 1 \mathrm{H}, J=2.3 \mathrm{~Hz}, \mathrm{CH}-\mathrm{Trp}), 6.70(\mathrm{~d}, 1 \mathrm{H}, J=2.0 \mathrm{~Hz}, \mathrm{NH}$-amide), $5.54(\mathrm{dd}, 1 \mathrm{H} J=5.2$ and $3.6 \mathrm{~Hz}$, $\mathrm{CH}^{*}$-Trp), 4.46 (qd, $1 \mathrm{H}, J=6.9$ and $2.8 \mathrm{~Hz}, \mathrm{CH}^{*}$-ala), $3.78\left(\mathrm{dd}, 1 \mathrm{H}, J=14.9\right.$ and $\left.5.3 \mathrm{~Hz}, \mathrm{CH}_{2}-\operatorname{Trp}\right), 3.70$ $\left(\mathrm{dd}, 1 \mathrm{H}, J=14.9\right.$ and $\left.3.4 \mathrm{~Hz}, \mathrm{CH}_{2}-\mathrm{Trp}\right), 0.58\left(\mathrm{~d}, 3 \mathrm{H}, J=7.0 \mathrm{~Hz}, \mathrm{CH}_{3}\right.$-ala); ${ }^{13} \mathrm{C} \mathrm{NMR}\left(75 \mathrm{MHz}, \mathrm{CDCl}_{3}\right): \delta$ $167.3(\mathrm{C}=\mathrm{O}), 161.0(\mathrm{C}=\mathrm{O}), 151.2(\mathrm{C}=\mathrm{N}), 147.2(\mathrm{C}), 135.7(\mathrm{C}-\operatorname{Trp}), 134.9(\mathrm{CH}), 127.9(\mathrm{C}-\operatorname{Trp}), 126.9(\mathrm{CH})$, 126.8 (CH), 126.7 (CH), 123.7 (CH-Trp), 122.3 (CH-Trp), 120.1 (C), 119.9 (CH-Trp), 118.7 (CH-Trp), 111.1 (CH-Trp), 109.4 (C-Trp), 56.9 ( $\mathrm{CH}^{*}$-Trp), $51.9\left(\mathrm{CH}^{*}\right.$-ala), $27.1\left(\mathrm{CH}_{2}\right.$-Trp), $22.8\left(\mathrm{CH}_{3}\right.$-ala. (+)-HRMS-ESI $m / z 359.1505(\mathrm{M}+\mathrm{H})^{+}$, (calculated for $\mathrm{C}_{21} \mathrm{H}_{18} \mathrm{~N}_{4} \mathrm{O}_{2}, 358.1430$ ).

\subsection{General Conditions for the Synthesis of Compound (1S,4S)-4-((1H-indol-3-yl)methyl)-1-((S)-sec-butyl) -1,2-dihydro-6H-pyrazino[2,1-b]quinazoline-3,6(4H)-dione (2)}

To a mixture of anthranilic acid (i, $287 \mathrm{mg}, 2.39 \mathrm{mmol})$ and TBTU $(920 \mathrm{mg}, 2.86 \mathrm{mmol}, 1.2$ equiv) in acetonitrile $(20 \mathrm{~mL}), \mathrm{Et}_{3} \mathrm{~N}(833 \mu \mathrm{L}, 4.78 \mathrm{mmol}, 2$ equiv) and L-tryptophan methyl ester (vi, $521 \mathrm{mg}$, $2.39 \mathrm{mmol}$ ) were added at room temperature. After stirring for $5 \mathrm{~h}$, the reaction mixture was concentrated under reduced pressure. The residue was dissolved in $\mathrm{CH}_{2} \mathrm{Cl}_{2}$ and washed with $1 \mathrm{M}$ $\mathrm{HCl}$, extracted with $\mathrm{CH}_{2} \mathrm{Cl}_{2}(3 \times 100 \mathrm{~mL})$, dried with $\mathrm{Na}_{2} \mathrm{SO}_{4}$, filtered, and concentrated. The residue was purified by flash chromatography (eluent $1 \% \mathrm{MeOH}$ in $\mathrm{CH}_{2} \mathrm{Cl}_{2}$ ) to yield vii as a white solid. ${ }^{1} \mathrm{H}$ NMR and ${ }^{13} \mathrm{C}$ NMR referred to the previous work [16]. To a solution of vii (304 $\mathrm{mg}, 0.901 \mathrm{mmol}$ ) in dried $\mathrm{CH}_{2} \mathrm{Cl}_{2}$ (30 mL), N-Fmoc-L-isoleucine- $\mathrm{Cl}$ [30] (viii, $395 \mathrm{mg}, 1.08 \mathrm{mmol}$ ) was added. The mixture was stirred for $30 \mathrm{~min}$, followed by addition of aqueous $\mathrm{Na}_{2} \mathrm{CO}_{3}(1 \mathrm{M}, 16 \mathrm{~mL}, 16 \mathrm{mmol})$. After continuous stirring for $3 \mathrm{~h}$, the mixture was extracted with $\mathrm{CH}_{2} \mathrm{Cl}_{2}(4 \times 100 \mathrm{~mL})$, dried with $\mathrm{Na}_{2} \mathrm{SO}_{4}$, filtered, and concentrated. The residue was purified by flash chromatography (eluent: $5 \% \mathrm{MeOH}$ in $\mathrm{CH}_{2} \mathrm{Cl}_{2}$ to give ix $(475.8 \mathrm{mg}, 86.2 \%)$ as a white solid. ${ }^{1} \mathrm{H}$ NMR $\left(300 \mathrm{MHz}, \mathrm{CDCl}_{3}\right): \delta 11.43(\mathrm{~s}, 1 \mathrm{H})$, $8.59(\mathrm{~d}, 1 \mathrm{H}, J=8.3 \mathrm{~Hz}), 8.19(\mathrm{~s}, 1 \mathrm{H}), 7.76(\mathrm{~d}, 2 \mathrm{H} \mathrm{J}=7.4 \mathrm{~Hz}), 7.69-7.56(\mathrm{~m}, 2 \mathrm{H}), 7.53-7.28(\mathrm{~m}, 7 \mathrm{H}), 7.17$ $(\mathrm{t}, 1 \mathrm{H}, J=7.3 \mathrm{~Hz}), 7.06(\mathrm{t}, 1 \mathrm{H}, J=7.4 \mathrm{~Hz}), 7.01(\mathrm{~d}, 1 \mathrm{H}, J=7.6 \mathrm{~Hz}), 6.96(\mathrm{~d}, 1 \mathrm{H}, J=3.5 \mathrm{~Hz}), 6.72(\mathrm{~d}$, $1 \mathrm{H}, J=7.6 \mathrm{~Hz}), 5.55(\mathrm{~d}, 1 \mathrm{H}, J=8.4 \mathrm{~Hz}), 5.06(\mathrm{dd}, 1 \mathrm{H}, J=12.6$ and $5.2 \mathrm{~Hz}), 4.39(\mathrm{dd}, 2 \mathrm{H}, J=16.4$ and $9.1 \mathrm{~Hz}), 3.73(\mathrm{~s}, 3 \mathrm{H}), 3.37(\mathrm{~m}, 2 \mathrm{H}), 2.11-2.00(\mathrm{~m}, 1 \mathrm{H}), 1.68-1.48(\mathrm{~m}, 2 \mathrm{H}), 1.03(\mathrm{~d}, 3 \mathrm{H}, J=6.8 \mathrm{~Hz}), 0.96(\mathrm{t}$, $3 \mathrm{H}, J=7.3 \mathrm{~Hz}$ ) and ${ }^{13} \mathrm{C} \mathrm{NMR}\left(75 \mathrm{MHz}, \mathrm{CDCl}_{3}\right) 172.1,170.2,168.6,144.1,143.8,141.3,139.0,136.1,132.9$, 127.7, 127.5, 127.1, 127.1, 126.9, 125.3, 125.2, 123.2, 122.8, 122.4, 121.4, 120.2, 120.0, 119.8, 118.5, 111.4, $109.7,67.2,61.3,53.3,52.6,47.3,37.9,31.4,27.3,15.8,11.7$. To a solution of $\mathbf{i x}(291.5 \mathrm{mg}, 0.432 \mathrm{mmol})$ 
in dried $\mathrm{CH}_{2} \mathrm{Cl}_{2}$ (20 mL) $\mathrm{Ph}_{3} \mathrm{P}$ (565 mg, $2.16 \mathrm{mmol}, 5$ equiv), $\mathrm{I}_{2}$ (448 mg, $2.12 \mathrm{mmol} .4 .9$ equiv), and $N, N$-diisopropylethylamine $(753 \mu \mathrm{L}, 4.32 \mathrm{mmol}, 10$ equiv) were added. The reaction mixture was stirred at room temperature for $5 \mathrm{~h}$, quenched with aqueous $\mathrm{Na}_{2} \mathrm{CO}_{3}$, and extracted with $\mathrm{CH}_{2} \mathrm{Cl}_{2}$ $(3 \times 100 \mathrm{~mL})$, dried with $\mathrm{Na}_{2} \mathrm{SO}_{4}$, filtered, and concentrated. Hexane was added to remove an excess of $\mathrm{Ph}_{3} \mathrm{P}$, the precipitate was filtered and was treated with $\mathrm{CH}_{2} \mathrm{Cl}_{2}(10 \mathrm{~mL})$ and piperidine $(2.5 \mathrm{~mL}$, $20 \%$ ) at room temperature for $20 \mathrm{~min}$, followed by solvent evaporation to provide the solid which was triturated with hexane $(1 \times 200 \mathrm{~mL}), \mathrm{CH}_{2} \mathrm{Cl}_{2} / \mathrm{PhMe}(1 \times 200 \mathrm{~mL})$, and hexane $(1 \times 200 \mathrm{~mL})$. The vacuum-dried crude residue was dissolved in $\mathrm{CH}_{3} \mathrm{CN}(10 \mathrm{~mL})$ in the presence of DMAP (158 mg, $1.39 \mathrm{mmol}$ ) and refluxed for $19 \mathrm{~h}$. The reaction mixture was purified by preparative TLC (EtOAc: MeOH: $\mathrm{CH}_{2} \mathrm{Cl}_{2}, 50: 2.5: 47.5$ ) to afford 2. Yield: $36 \mathrm{mg}, 36.2 \%$; enantiomeric ratio (er) = 73:27; m.p: $181-183{ }^{\circ} \mathrm{C} ;[\alpha]_{D}^{30}=+346.40\left(c 0.051 ; \mathrm{CHCl}_{3}\right) ; v_{\max }(\mathrm{KBr}) 3375,3187,2880,1684,1662,1472,1434$, and $12611 \mathrm{~cm}^{-1} ;{ }^{1} \mathrm{H}$ NMR (300 MHz, $\left.\mathrm{CDCl}_{3}\right): \delta 8.38(\mathrm{dd}, 1 \mathrm{H}, J=8.0$ and $1.1 \mathrm{~Hz}, \mathrm{CH}), 8.07(\mathrm{br}, 1 \mathrm{H}, \mathrm{NH}-\mathrm{Trp})$, $7.79(\mathrm{ddd}, 1 \mathrm{H}, J=8.5,7.1$, and $1.6 \mathrm{~Hz}, \mathrm{CH}), 7.62(\mathrm{dd}, J=8.2$ and $0.5 \mathrm{~Hz}, \mathrm{CH}), 7.54(\mathrm{ddd}, 1 \mathrm{H}, J=8.2$, 7.2, and $1.2 \mathrm{~Hz}, \mathrm{CH}), 7.48(\mathrm{~d}, 1 \mathrm{H}, J 7.9 \mathrm{~Hz}, \mathrm{CH}-\operatorname{Trp}), 7.28(\mathrm{~d}, 1 \mathrm{H}, J=8.5 \mathrm{~Hz}, \mathrm{CH}-\operatorname{Trp}), 7.12$ (ddd, 1H, $J=8.1,7.1$ and $1.1 \mathrm{~Hz}, \mathrm{CH}-\operatorname{Trp}), 6.94(\mathrm{ddd}, 1 \mathrm{H}, J=8.0,7.1$ and $1.0 \mathrm{~Hz}, \mathrm{CH}-\operatorname{Trp}), 6.87(\mathrm{~d}, 1 \mathrm{H}, J=2.3 \mathrm{~Hz}$, CH-Trp), $6.55\left(\mathrm{~d}, 1 \mathrm{H}, J=3.1 \mathrm{~Hz}, \mathrm{NH}\right.$-amide), $5.52\left(\mathrm{dd}, 1 \mathrm{H}, J=6.4\right.$ and $\left.3.6 \mathrm{~Hz}, \mathrm{CH}^{*}-\operatorname{Trp}\right), 4.03(\mathrm{dd}, 1 \mathrm{H}$, $J=8.0$ and $3.5 \mathrm{~Hz}, \mathrm{CH}-\mathrm{Ile}), 3.83\left(\mathrm{dd}, 1 \mathrm{H}, J=14.9\right.$ and $\left.6.4 \mathrm{~Hz}, \mathrm{CH}_{2}-\mathrm{Trp}\right), 3.73(\mathrm{dd}, 1 \mathrm{H}, J=14.8$ and $3.5 \mathrm{~Hz}$, $\mathrm{CH}_{2}$-Trp), 0.99-0.85 (m, 1H, CH*-Ile), 0.85-0.69 (m, 2H, $\mathrm{CH}_{2}$-Ile), 0.66 (d, 3H, J = 6.5 Hz, $\left.\mathrm{CH}_{3}-\mathrm{Ile}\right), 0.58$ $\left(\mathrm{t}, 3 \mathrm{H} \mathrm{J}=7.1 \mathrm{~Hz}, \mathrm{CH}_{3}-\mathrm{Ile}\right) ;{ }^{13} \mathrm{C} \mathrm{NMR}\left(75 \mathrm{MHz} \mathrm{CDCl}_{3}\right): \delta 167.8(\mathrm{C}=\mathrm{O}), 161.4(\mathrm{C}=\mathrm{O}), 149.4(\mathrm{C}=\mathrm{N}), 146.8$ (C), 135.9 (C-Trp), $134.7(\mathrm{CH}), 127.9$ (C-Trp), $127.1(\mathrm{CH}), 127.1(\mathrm{CH}), 126.8(\mathrm{CH}), 123.5(\mathrm{CH}-\operatorname{Trp}), 122.3$ (CH-Trp), $120.3(\mathrm{C}), 120.0$ (CH-Trp), 119.0 (CH-Trp), 111.0 (CH-Trp), 110.2 (C-Trp), 60.8 (CH*-Ile), 57.6 (CH*-Trp), 40.8 (CH*-Ile), 27.1 ( $\mathrm{CH}_{2}$-Trp), 24.3 ( $\mathrm{CH}_{2}$-Ile), 15.3 ( $\mathrm{CH}_{3}$-Ile), 10.4 ( $\mathrm{CH}_{3}$-Ile); (+)-HREM-ESI $m / z 401.1967(\mathrm{M}+\mathrm{H})^{+}, 423.1787(\mathrm{M}+\mathrm{Na})^{+}$(calculated for $\left.\mathrm{C}_{24} \mathrm{H}_{25} \mathrm{~N}_{4} \mathrm{O}_{2}, 400.1899\right)$.

\subsection{General Conditions for the Synthesis of Quinazolinone-3,6-(4H)-Diones Compound 4, 5, 6, 7, 8, and 9}

In a closed vial anthranilic acid (i, $28 \mathrm{mg}, 200 \mu \mathrm{mol}), N$-Boc-L-isoleucine $(\mathbf{x}, 44 \mathrm{mg}, 200 \mu \mathrm{mol})$ for 4 and 5, or N-Boc-L-methionine (xi, $46 \mathrm{mg}, 200 \mu \mathrm{mol})$ for 6 and 7, or N-Boc-o-Bn-Tyrosine (xii, $74 \mathrm{mg}$, $200 \mu \mathrm{mol})$ for 8 and 9, and triphenylphosphite $(63 \mu \mathrm{L}, 220 \mu \mathrm{mol})$ were added along with $1 \mathrm{~mL}$ of dried pyridine. The vial was heated in heating block with stirring at $55{ }^{\circ} \mathrm{C}$ for $16-24 \mathrm{~h}$. After cooling the mixture to room temperature, D-tryptophan methyl ester hydrochloride (ii) for 5, and 7, L-tryptophan methyl ester hydrochloride (vi) for 4, 6, 8 and 9 (51 mg, $200 \mu \mathrm{mol}$ ) was added, and the mixture was irradiated in the microwave at the constant temperature at $220{ }^{\circ} \mathrm{C}$ for $1.5 \mathrm{~min}$. Reaction mixtures were prepared in the same conditions and treated in parallel. After removing the solvent with toluene, the crude product was purified by flash column chromatography using hexane:EtOAc (60:40) as a mobile phase. The preparative TLC was performed using $\mathrm{CH}_{2} \mathrm{Cl}_{2}: \mathrm{Me}_{2} \mathrm{CO}$ (95:5) as mobile phase. The major compound appeared as a black spot with no fluorescence under the UV light (366 nm). The desirable compounds $4,5,6,7,8$, and 9 were collected as yellow solids. Before analysis, compounds were recrystallized from methanol.

(1R,4S)-4-((1H-indol-3-yl)methyl)-1-((S)-sec-butyl)-1,2-dihydro-6H-pyrazino[2,1-b]quinazoline-3,6(4H)- dione (4). Yield: $29.2 \mathrm{mg}, 7.1 \%$; er = 3:97; m.p: $220-22{ }^{\circ} \mathrm{C} ;[\alpha]_{D}^{30}=+484.7\left(c 0.037 ; \mathrm{CHCl}_{3}\right) ; v_{\max }(\mathrm{KBr}) 3373$, 3059, 2880, 1684, 1662, 1472, 1434, and $1261 \mathrm{~cm}^{-1} ;{ }^{1} \mathrm{H}$ NMR $\left(300 \mathrm{MHz}, \mathrm{CDCl}_{3}\right): \delta 8.38(\mathrm{dd}, 1 \mathrm{H}$, $J=7.9$ and $1.2 \mathrm{~Hz}, \mathrm{CH}), 8.07(\mathrm{br}, 1 \mathrm{H}, \mathrm{NH}-\mathrm{Trp}), 7.78(\mathrm{ddd}, 1 \mathrm{H}, J=8.4,7.1$, and 1.6 Hz, CH), 7.57 (d, $J=8.0 \mathrm{~Hz}, \mathrm{CH}), 7.52(\mathrm{~d}, 1 \mathrm{H}, J=6.0 \mathrm{~Hz}, \mathrm{CH}), 7.47(\mathrm{~d}, 1 \mathrm{H}, J=8.0 \mathrm{~Hz}, \mathrm{CH}-\operatorname{Trp}), 7.28(\mathrm{~d}, 1 \mathrm{H}, J=8.2 \mathrm{~Hz}$, CH-Trp), 7.12 (t, 1H, J = 7.1 Hz, CH-Trp), 6.96 (t, 1H, J = 7.5 Hz, CH-Trp), 6.57 (d, 1H, J = 2.4 Hz, CH-Trp), 5.68 (dd, 1H, J = 5.2 and $2.7 \mathrm{~Hz}, \mathrm{CH}^{*}$-Trp), 5.64 (s, 1H, NH-amide), 3.76 (dd, 1H, $J=14.8$ and 2.7 Hz, $\mathrm{CH}_{2}-\operatorname{Trp}$ ), $3.63\left(\mathrm{dd}, 1 \mathrm{H}, J=14.9\right.$ and $5.3 \mathrm{~Hz}, \mathrm{CH}_{2}-\operatorname{Trp}$ ), 2.80 (d, 1H, J = 2.4 Hz, CH*-Ile), 2.36 (dt, 1H, J 14.9 and $7.5 \mathrm{~Hz}, \mathrm{CH}^{*}$-Ile), $0.98\left(\mathrm{~m}, 2 \mathrm{H}, \mathrm{CH}_{2}\right.$-Ile), 0.88 (d, 3H, J = 6.5 Hz, CH $\left.-\mathrm{Ile}\right), 0.64$ (t, $\left.3 \mathrm{H} J=6.4 \mathrm{~Hz}, \mathrm{CH}_{3}-\mathrm{Ile}\right) ;{ }^{13} \mathrm{C}$ NMR $\left(75 \mathrm{MHz} \mathrm{CDCl}_{3}\right): \delta 169.5(\mathrm{C}=\mathrm{O}), 160.9(\mathrm{C}=\mathrm{O}), 150.7(\mathrm{C}=\mathrm{N}), 147.1$ (C), 136.1 (C-Trp), $134.7(\mathrm{CH}), 127.2(\mathrm{CH}), 127.1(\mathrm{CH}), 127.0(\mathrm{C}-\operatorname{Trp}), 126.9(\mathrm{CH}), 123.6$ (CH-Trp), 122.8 (CH-Trp), 120.2 (C), 120.1 (C-Trp), 118.8 (CH-Trp), 111.1 (CH-Trp), 109.4 (C-Trp), 56.8 (CH*-Trp), 55.1 
( $\mathrm{CH}^{*}$-Ile), 35.8 ( $\mathrm{CH}^{*}$-Ile), $27.4\left(\mathrm{CH}_{2}\right.$-Trp), $25.8\left(\mathrm{CH}_{2}\right.$-Ile), $13.2\left(\mathrm{CH}_{3}\right.$-Ile), $11.0\left(\mathrm{CH}_{3}\right.$-Ile; (+)-HRMS-ESI $m / z 401.1964(\mathrm{M}+\mathrm{H})^{+}$(calculated for $\mathrm{C}_{24} \mathrm{H}_{25} \mathrm{~N}_{4} \mathrm{O}_{2}, 400.1899$ ).

(1S,4R)-4-((1H-indol-3-yl)methyl)-1-((S)-sec-butyl)-1,2-dihydro-6H-pyrazino[2,1-b]quinazoline-3,6(4H)-dione (5). Yield: $27.2 \mathrm{mg}, 6.6 \%$; er = 3:97; m.p: $218-220{ }^{\circ} \mathrm{C} ;[\alpha]_{D}^{30}=-372.6\left(c 0.034 ; \mathrm{CHCl}_{3}\right) ; v_{\max }(\mathrm{KBr}) 3373$, $3059,2880,1684,1662,1472,1434,1261 \mathrm{~cm}^{-1},{ }^{1} \mathrm{H}$ NMR $\left(300 \mathrm{MHz}, \mathrm{CDCl}_{3}\right): \delta 8.37(\mathrm{dd}, 1 \mathrm{H}, J=7.9$ and $1.2 \mathrm{~Hz}, \mathrm{CH}), 8.07(\mathrm{br}, 1 \mathrm{H}, \mathrm{NH}-\mathrm{Trp}), 7.78(\mathrm{ddd}, 1 \mathrm{H}, J=8.4,7.1$, and $1.6 \mathrm{~Hz}, \mathrm{CH}), 7.57(\mathrm{~d}, J=8.0 \mathrm{~Hz}$, $\mathrm{CH}), 7.52(\mathrm{~d}, 1 \mathrm{H}, J=6.0 \mathrm{~Hz}, \mathrm{CH}), 7.47(\mathrm{~d}, 1 \mathrm{H}, J=8.0 \mathrm{~Hz}, \mathrm{CH}-\operatorname{Trp}), 7.28(\mathrm{~d}, 1 \mathrm{H}, J=8.2 \mathrm{~Hz}, \mathrm{CH}-\operatorname{Trp})$, $7.12(\mathrm{t}, 1 \mathrm{H}, J=7.1 \mathrm{~Hz}, \mathrm{CH}-\operatorname{Trp}), 6.96(\mathrm{t}, 1 \mathrm{H}, J=7.5 \mathrm{~Hz}, \mathrm{CH}-\operatorname{Trp}), 6.57$ (d, 1H, $J=2.4 \mathrm{~Hz}, \mathrm{CH}$-indole), $5.68\left(\mathrm{dd}, 1 \mathrm{H}, J=5.2\right.$ and $\left.2.7 \mathrm{~Hz}, \mathrm{CH}^{*}-\mathrm{Trp}\right), 5.52(\mathrm{~s}, 1 \mathrm{H}, \mathrm{NH}$-amide), $3.76(\mathrm{dd}, 1 \mathrm{H}, J=14.8$ and $2.7 \mathrm{~Hz}$, $\mathrm{CH}_{2}$-Trp), $3.63\left(\mathrm{dd}, 1 \mathrm{H}, J=14.9\right.$ and $\left.5.3 \mathrm{~Hz}, \mathrm{CH}_{2}-\mathrm{Trp}\right), 2.80\left(\mathrm{~d}, 1 \mathrm{H}, J=2.4 \mathrm{~Hz}, \mathrm{CH}^{*}-\mathrm{Ile}\right), 2.37(\mathrm{dt}, 1 \mathrm{H}$, $J=14.9$ and $7.5 \mathrm{~Hz}, \mathrm{CH}^{*}$-Ile), $0.88\left(\mathrm{~m}, 2 \mathrm{H}, J=6.7 \mathrm{~Hz}, \mathrm{CH}_{2}\right.$-Ile), $0.62\left(\mathrm{~d}, 3 \mathrm{H}, J=6.5 \mathrm{~Hz}, \mathrm{CH}_{3}\right.$-Ile), $0.46(\mathrm{t}$, $\left.3 \mathrm{H} \mathrm{J}=6.4 \mathrm{~Hz}, \mathrm{CH}_{3}-\mathrm{Ile}\right) ;{ }^{13} \mathrm{C} \mathrm{NMR}\left(75 \mathrm{MHz}, \mathrm{CDCl}_{3}\right): \delta 169.4(\mathrm{C}=\mathrm{O}), 160.9(\mathrm{C}=\mathrm{O}), 150.1(\mathrm{C}=\mathrm{N}), 147.1(\mathrm{C})$, 136.1 (C-Trp), $134.7(\mathrm{CH}), 127.2(\mathrm{CH}), 127.2(\mathrm{CH}), 127.0$ (CH-Trp), $126.9(\mathrm{CH}), 123.6$ (CH-Trp), 122.7 (CH-Trp), 120.2 (C), 120.1 (C-Trp), 118.8 (CH-Trp), 111.1 (CH-Trp), 109.4 (C-indol), 56.8 ( CH $^{*}$-Trp), 55.5 ( $\mathrm{CH}^{*}$-Ile), 35.6 ( $\mathrm{CH}^{*}$-Ile), $27.4\left(\mathrm{CH}_{2}\right.$-Trp $), 25.9\left(\mathrm{CH}_{2}\right.$-Ile), $13.2\left(\mathrm{CH}_{3}\right.$-Ile), $11.0\left(\mathrm{CH}_{3}\right.$-Ile; (+)-HRMS-ESI $\mathrm{m} / \mathrm{z} 401.1973(\mathrm{M}+\mathrm{H})^{+}$(calculated for $\mathrm{C}_{24} \mathrm{H}_{25} \mathrm{~N}_{4} \mathrm{O}_{2}, 400.1899$ ).

(1R,4S)-4-((1H-indol-3-yl)methyl)-1-(2-(methylthio)ethyl)-1,2-dihydro-6H-pyrazino[2,1-b]quinazoline-3,6(4H)diones (6). Yield: $27 \mathrm{mg}, 6.1 \%$; m.p: $198-200.7^{\circ} \mathrm{C} ;[\alpha]_{D}^{30}=+74.1\left(c 0.045 ; \mathrm{CHCl}_{3}\right) ; v_{\max }(\mathrm{KBr}) 3295,3067$, 2915, 1682, 1600, 1470, 770, and $697 \mathrm{~cm}^{-1} ;{ }^{1} \mathrm{H}$ NMR $\left(300 \mathrm{MHz}, \mathrm{CDCl}_{3}\right): \delta 8.37(\mathrm{dd}, 1 \mathrm{H}, J=8.0$ and $1.2 \mathrm{~Hz}$, $\mathrm{CH}), 8.07$ (br, $1 \mathrm{H}, \mathrm{NH}-\mathrm{Tr} p), 7.78(\mathrm{ddd}, 1 \mathrm{H}, J=8.4,7.0$, and $1.5 \mathrm{~Hz}, \mathrm{CH}), 7.57(\mathrm{~d}, 1 \mathrm{H}, J=2.5 \mathrm{~Hz}, \mathrm{CH})$, $7.53(\mathrm{dd}, 1 \mathrm{H}, J=8.2$ and $1.1 \mathrm{~Hz}, \mathrm{CH}), 7.41(\mathrm{~d}, 1 \mathrm{H}, J=8.0 \mathrm{~Hz}, \mathrm{CH}-\operatorname{Trp}), 7.30(\mathrm{~d}, 1 \mathrm{H}, J=8.3 \mathrm{~Hz}, \mathrm{CH}-\operatorname{Trp})$, $7.13(\mathrm{t}, 1 \mathrm{H}, J=7.7 \mathrm{~Hz}, \mathrm{CH}-\operatorname{Trp}), 6.93(\mathrm{t}, 1 \mathrm{H}, J=7.0 \mathrm{~Hz}, \mathrm{CH}-\operatorname{Trp}), 6.71(\mathrm{~d}, 1 \mathrm{H}, J=2.4 \mathrm{~Hz}, \mathrm{CH}-\operatorname{Trp}), 6.37$ (s, $1 \mathrm{H}, \mathrm{NH}$-amide), $5.67\left(\mathrm{dd}, 1 \mathrm{H}, J=5.2\right.$ and $3.0 \mathrm{~Hz}, \mathrm{CH}^{*}$-Trp), $3.74\left(\mathrm{dd}, 1 \mathrm{H}, J=15.0\right.$ and $3.0 \mathrm{~Hz}, \mathrm{CH}_{2}$-Trp), $3.65\left(\mathrm{dd}, 1 \mathrm{H}, J=14.9\right.$ and $\left.5.3 \mathrm{~Hz}, \mathrm{CH}_{2}-\mathrm{Trp}\right), 2.99$ (dd, $1 \mathrm{H}, J=6.6$ and $\left.3.6 \mathrm{~Hz}, \mathrm{CH}^{*}-\mathrm{Met}\right), 2.49-2.13(\mathrm{~m}, 4 \mathrm{H}$, $\mathrm{CH}_{2}$-Met), 1.96 (s, 3H, CH $\left.{ }_{3}-\mathrm{Met}\right) ;{ }^{13} \mathrm{C}$ NMR $\left(75 \mathrm{MHz}, \mathrm{CDCl}_{3}\right): \delta 169.3(\mathrm{C}=\mathrm{O}), 161.1(\mathrm{C}=\mathrm{O}), 150.3(\mathrm{C}=\mathrm{N})$, 147.1 (C), 136.0 (C-Trp), 134.7 (CH), 127.2 (CH), 127.2 (C-Trp), 126.9 (CH), 123.5 (CH-Trp), 122.7 (CH-Trp), 120.2 (C), 120.2 (C-Trp), 118.7 (CH-Trp), 111.1 (CH-Trp), 109.5 (C-Trp), $57.2\left(\mathrm{CH}^{*} \operatorname{Trp}\right), 52.8$ (CH*-Met), 30.7 ( $\mathrm{CH}_{2}$-S-Met), $29.7\left(\mathrm{CH}_{2}\right.$-Met), $27.2\left(\mathrm{CH}_{2}\right.$-Trp), $15.3\left(\mathrm{CH}_{3}\right.$-Met); HRMS-ESI m/z $419.1544(\mathrm{M}+\mathrm{H})^{+}$ (calculate for $\mathrm{C}_{23} \mathrm{H}_{23} \mathrm{~N}_{4} \mathrm{O}_{2} \mathrm{~S}, 418.1463$ ).

(1S,4R)-4-((1H-indol-3-yl)methyl)-1-(2-(methylthio)ethyl)-1,2-dihydro-6H-pyrazino[2,1-b]quinazoline-3,6(4H)diones (7). Yield: $34.8 \mathrm{mg}, 7.9 \%$; $\mathrm{er}=49$ : 51; m.p.: $197-200{ }^{\circ} \mathrm{C} ;[\alpha]_{D}^{30}=-56.9\left(c 0.041 ; \mathrm{CHCl}_{3}\right) ; v_{\max }$ (KBr) 3290, 3058, 2918, 2854, 1684, 1670, 1602, 773, and $695 \mathrm{~cm}^{-1} ;{ }^{1} \mathrm{H}$ NMR $\left(300 \mathrm{MHz}, \mathrm{CDCl}_{3}\right): \delta 8$. $37(\mathrm{dd}, 1 \mathrm{H}, J=8.0$ and $1.1 \mathrm{~Hz}, \mathrm{CH}), 8.12(\mathrm{br}, 1 \mathrm{H}, \mathrm{NH}-\mathrm{Trp}), 7.78$ (ddd, $1 \mathrm{H}, J=8.4,7.2$, and $1.5 \mathrm{~Hz}$, $\mathrm{CH}), 7.57(\mathrm{~d}, J=8.3 \mathrm{~Hz}, \mathrm{CH}), 7.54(\mathrm{~d}, 1 \mathrm{H}, J=7.0 \mathrm{~Hz}, \mathrm{CH}), 7.40(\mathrm{~d}, 1 \mathrm{H}, J=8.0 \mathrm{~Hz}, \mathrm{CH}-\operatorname{Trp}), 7.30$ (d, $1 \mathrm{H}, J=8.2 \mathrm{~Hz}, \mathrm{CH}-\operatorname{Trp}), 7.12(\mathrm{t}, 1 \mathrm{H}, J=7.1 \mathrm{~Hz}, \mathrm{CH}-\operatorname{Trp}), 6.92(\mathrm{t}, 1 \mathrm{H}, J=7.0 \mathrm{~Hz}, \mathrm{CH}-\operatorname{Trp}), 6.71(\mathrm{~d}, 1 \mathrm{H}$, $J=2.4 \mathrm{~Hz}, \mathrm{CH}-\mathrm{Trp}), 5.67\left(\mathrm{dd}, 1 \mathrm{H}, J=5.4\right.$ and $3.1 \mathrm{~Hz}, \mathrm{CH}^{*}$-Trp), 6.54 (s, 1H, NH-amide), 3.73 (dd, $1 \mathrm{H}$, $J=15.0$ and $\left.2.9 \mathrm{~Hz}, \mathrm{CH}_{2}-\mathrm{Trp}\right), 3.65\left(\mathrm{dd}, 1 \mathrm{H}, J=15.1\right.$ and $\left.5.5 \mathrm{~Hz}, \mathrm{CH}_{2}-\mathrm{Trp}\right), 3.01(\mathrm{dd}, 1 \mathrm{H}, J=6.6$ and $3.6 \mathrm{~Hz}, \mathrm{CH}^{*}$-Met), 2.48-2.20 (m, 4H, $\mathrm{CH}_{2}$-Met), 1.96 (s, 3H, $\left.\mathrm{CH}_{3}-\mathrm{Met}\right) ;{ }^{13} \mathrm{C} \mathrm{NMR}\left(75 \mathrm{MHz}, \mathrm{CDCl}_{3}\right.$ ): $\delta$ $169.5(\mathrm{C}=\mathrm{O}), 161.0(\mathrm{C}=\mathrm{O}), 150.6(\mathrm{C}=\mathrm{N}), 146.9(\mathrm{C}), 136.1(\mathrm{C}-\operatorname{Trp}), 134.7(\mathrm{CH}), 127.2(\mathrm{C}-\operatorname{Trp}), 127.2(\mathrm{CH})$, 126.9 (CH), 123.5 (CH-Trp), 122.6 (CH-Trp), 120.2 (C), 120.1 (C-Trp), 118.7 (CH-Trp), 111.2 (CH-Trp), 109.5 (C-Trp), 57.2 ( $\mathrm{CH}^{*}$-Trp), $52.8\left(\mathrm{CH}^{*}\right.$-Met), 30.7 ( $\mathrm{CH}_{2}$-S-Met), $29.7\left(\mathrm{CH}_{2}\right.$-Met), $27.2\left(\mathrm{CH}_{2}-\mathrm{Trp}\right), 15.3$ $\left(\mathrm{CH}_{3}\right.$-Met); (+)-HRMS-ESI $m / z 419.1526(\mathrm{M}+\mathrm{H})^{+}$, (calculated for $\mathrm{C}_{23} \mathrm{H}_{23} \mathrm{~N}_{4} \mathrm{O}_{2} \mathrm{~S}, 418.1463$ ).

(1R,4S)-4-((1H-indol-3-yl)methyl)-1-(4-(benzyloxy)benzyl)-1,2-dihydro-6H-pyrazino[2,1-b]quinazoline-3,6(4H)diones (8). Yield: $81.9 \mathrm{mg}, 14.8 \%$; er $=63: 37$; m.p.: $226.9-227.9^{\circ} \mathrm{C} ;[\alpha]_{D}^{30}=+46.7\left(c 0.05 ; \mathrm{CHCl}_{3}\right) ; v_{\max }$ (KBr) 3393, 3268, 2954, 1671, 1611, 1511, 1465, 1240, 772, and $697 \mathrm{~cm}^{-1} ;{ }^{1} \mathrm{H}$ NMR (300 MHz, $\left.\mathrm{CDCl}_{3}\right)$ : $\delta 8.39(\mathrm{dd}, 1 \mathrm{H}, J=8.0$ and $1.2 \mathrm{~Hz}, \mathrm{CH}), 8.05(\mathrm{br}, 1 \mathrm{H}, \mathrm{NH}-\mathrm{Trp}), 7.80(\mathrm{ddd}, 1 \mathrm{H}, J=8.5,7.2$ and $1.5 \mathrm{~Hz}$, $\mathrm{CH}), 7.62(\mathrm{~d}, J=8.0 \mathrm{~Hz}, \mathrm{CH}), 7.56(\mathrm{dt}, 1 \mathrm{H}, J=7.3,7.7$, and $1.1 \mathrm{~Hz}, \mathrm{CH}), 7.45-7.39(\mathrm{~m}, 5 \mathrm{H}, \mathrm{CH}-\mathrm{Bz})$, $7.32(\mathrm{~d}, 2 \mathrm{H}, J=8.0 \mathrm{~Hz}, \mathrm{CH}-\operatorname{Trp}), 7.17$ (t, 1H, J = 7.5 Hz, CH-Trp), 6.88 (t, 1H, J = 7.5 Hz, CH-Trp), 
$6.76(\mathrm{~d}, 2 \mathrm{H}, J=9.0 \mathrm{~Hz}, \mathrm{CH}-\mathrm{Tyr}), 6.61$ (d, 1H, J = 3.0 Hz, CH-Trp), 6.39 (d, 2H, J = 8.5 Hz, CH-Tyr), $5.64\left(\mathrm{dd}, 1 \mathrm{H}, J=5.2\right.$ and 2.7, $\left.\mathrm{CH}^{*}-\mathrm{Trp}\right), 5.35\left(\mathrm{~s}, 1 \mathrm{H}, \mathrm{NH}\right.$-amide), $5.05\left(\mathrm{~s}, 2 \mathrm{H}, \mathrm{CH}_{2}-\mathrm{Bz}\right), 3.76(\mathrm{dd}, 1 \mathrm{H}$, $J=14.9$ and $\left.2.6 \mathrm{~Hz}, \mathrm{CH}_{2}-\operatorname{Trp}\right), 3.67\left(\mathrm{dd}, 1 \mathrm{H}, J=15.0\right.$ and $\left.5.3 \mathrm{~Hz}, \mathrm{CH}_{2}-\operatorname{Trp}\right), 3.52(\mathrm{dd}, 1 \mathrm{H}, J=14.7$ and $\left.3.6 \mathrm{~Hz}, \mathrm{CH}_{2}-\mathrm{Tyr}\right), 2.89$ (dd, $J=11.1$ and $\left.3.6 \mathrm{~Hz}, \mathrm{CH}^{*}-\mathrm{Tyr}\right), 2.46\left(\mathrm{dd}, 1 \mathrm{H}, J=14.7\right.$ and $11.2 \mathrm{~Hz}, \mathrm{CH}_{2}-\mathrm{Tyr}$ ); ${ }^{13} \mathrm{C}$ NMR $\left(75 \mathrm{MHz}, \mathrm{CDCl}_{3}\right): \delta 169.2(\mathrm{C}=\mathrm{O}), 160.7(\mathrm{C}=\mathrm{O}), 157.9(\mathrm{C}-\mathrm{Tyr}), 151.0(\mathrm{C}=\mathrm{N}), 147.0(\mathrm{C}), 137.0$ (C-Trp), 136.1(C-Bz), 134.8 (CH), 128.7 (CH-Tyr (2)), 128.6 (CH-Bz (2)), 128.0 (C-Tyr), 127.4 (CH-Bz), 127.3 (CH-Trp), $127.2(\mathrm{CH}), 127.1$ (CH-Bz (2)), $127.0(\mathrm{CH}), 126.9$ (CH), 123.8 (CH-Trp), 122.8 (CH-Trp), 120.6 (C), 120.4 (CH-Trp), 119.0 (CH-Trp), 115.5 (CH-Tyr (2H)), 111.1 (CH-Trp), 109.7 (C-Trp), 70.1 ( $\mathrm{CH}_{2}$-Bz), 57.4 ( $\mathrm{CH}^{*}$-Trp), 52.9 ( $\mathrm{CH}^{*}$-Tyr), $37.1\left(\mathrm{CH}_{2}\right.$-Tyr), $29.7\left(\mathrm{CH}_{2}\right.$-Trp); (+)-HRMS-ESI m/z 541.2232 $(\mathrm{M}+\mathrm{H})^{+}$, (calculated for $\mathrm{C}_{34} \mathrm{H}_{29} \mathrm{~N}_{4} \mathrm{O}_{3}, 540.2161$ ).

(1S,4S)-4-((1H-indol-3-yl)methyl)-1-(4-(benzyloxy)benzyl)-1,2-dihydro-6H-pyrazino[2,1-b]quinazoline-3,6(4H)diones (9). Yield: $119.9 \mathrm{mg}, 21.7 \%$; $e r=29: 71 ; \mathrm{m} . \mathrm{p} .: 165.9-166.6^{\circ} \mathrm{C} ;[\alpha]_{D}^{30}=+205.8\left(c 0.076 ; \mathrm{CHCl}_{3}\right) ; v_{\max }$ (KBr) 3489, 3364, 2923, 1674, 1612, 1512, 1467, 1249, 774, and $695 \mathrm{~cm}^{-1} ;{ }^{1} \mathrm{H}$ NMR $\left(300 \mathrm{MHz}, \mathrm{CDCl}_{3}\right): \delta$ 8. $42(\mathrm{dd}, 1 \mathrm{H}, J=8.0$ and $1.1 \mathrm{~Hz}, \mathrm{CH}), 8.08(\mathrm{br}, 1 \mathrm{H}, \mathrm{NH}-\mathrm{Trp}), 7.83(\mathrm{ddd}, 1 \mathrm{H}, J$ 8.5, 7.1, and $1.5 \mathrm{~Hz}, \mathrm{CH}$ ), $7.66(\mathrm{~d}, J 7.7 \mathrm{~Hz}, \mathrm{CH}), 7.62-7.52(\mathrm{~m}, 2 \mathrm{H}, \mathrm{CH}), 7.39(\mathrm{t}, 4 \mathrm{H}, J=2.6 \mathrm{~Hz}, \mathrm{CH}-\mathrm{Bz}), 7.35$ (ddd, $J=6.2,3.4$, and $1.5 \mathrm{~Hz}, 1 \mathrm{H}, \mathrm{CH}-\mathrm{Bz}), 7.30(\mathrm{~d}, 1 \mathrm{H}, J=8.1 \mathrm{~Hz}, \mathrm{CH}-\mathrm{Trp}), 7.20(\mathrm{td}, 1 \mathrm{H}, J=7.6$ and $1.1 \mathrm{~Hz}, \mathrm{CH}-\mathrm{Trp}), 6.10$ (td, $1 \mathrm{H}$, $J=7.5$ and $1.0 \mathrm{~Hz}, \mathrm{CH}-\mathrm{Trp}), 6.74(\mathrm{~d}, 2 \mathrm{H}, J=8.7 \mathrm{~Hz}, \mathrm{CH}-\mathrm{Tyr}), 6.60(\mathrm{~d}, 1 \mathrm{H}, J=2.3 \mathrm{~Hz}, \mathrm{CH}-\operatorname{Trp}), 6.23$ (d, $2 \mathrm{H}, J=8.6 \mathrm{~Hz}, \mathrm{CH}-\mathrm{Tyr}), 5.56\left(\mathrm{t}, 1 \mathrm{H}, J=4.2 \mathrm{~Hz}, \mathrm{CH}^{*}-\mathrm{Trp}\right.$ ), 5.55 (s, 1H, NH-amide), 4.99 (s, 2H, $\mathrm{CH}_{2}-\mathrm{Bz}$ ), $4.33\left(\mathrm{dt}, 1 \mathrm{H}, J=11.7\right.$ and $\left.2.8 \mathrm{~Hz}, \mathrm{CH}^{*}-\mathrm{Tyr}\right), 3.86\left(\mathrm{dd}, 1 \mathrm{H}, J=14.9\right.$ and $\left.3.0 \mathrm{~Hz}, \mathrm{CH}_{2}-\mathrm{Trp}\right), 3.80(\mathrm{dd}, 1 \mathrm{H}$, $J=14.9$ and $\left.4.4 \mathrm{~Hz}, \mathrm{CH}_{2}-\mathrm{Trp}\right), 2.95\left(\mathrm{dd}, 1 \mathrm{H}, J=13.3\right.$ and $\left.3.1 \mathrm{~Hz}, \mathrm{CH}_{2}-\mathrm{Tyr}\right), 0.53(\mathrm{dd}, J=13.1$ and $11.9 \mathrm{~Hz}$, $\mathrm{CH}_{2}$-Tyr); ${ }^{13} \mathrm{C}$ NMR $\left(75 \mathrm{MHz}, \mathrm{CDCl}_{3}\right): \delta 166.5(\mathrm{C}=\mathrm{O}), 160.9(\mathrm{C}=\mathrm{O}), 158.0(\mathrm{C}-\mathrm{Tyr}), 150.2(\mathrm{C}=\mathrm{N}), 147.2$ (C), 136.9 (C-Trp), 135.8 (C-Bn), 134.9 (CH), 130.28 (CH-Tyr (2)), 128.6 (CH-Bz (2)), 128.1 (C-Tyr), 128.0 (CH-Bz), 127.7 (C-Trp), 127.4 (CH), 127.0 (CH-Bz (2)), 126.9 (CH), 123.5 (CH-Trp), 122.8 (CH-Trp), 120.5 (C), 120.2 (C-Trp), 119.5 (CH-Trp), 115.2 (CH-Tyr (2)), 111.4 (CH-Trp), 109.7 (C-Trp), $70.0\left(\mathrm{CH}_{2}-\mathrm{Bz}\right), 57.9$ ( $\mathrm{CH}^{*}$-Tyr), $56.8\left(\mathrm{CH}^{*}\right.$-Trp), $42.0\left(\mathrm{CH}_{2}-\mathrm{Tyr}\right), 26.6\left(\mathrm{CH}_{2}\right.$-Trp(+)-HRMS-ESI $\mathrm{m} / z 541.2221(\mathrm{M}+\mathrm{H})^{+}$, (calculated for $\mathrm{C}_{34} \mathrm{H}_{29} \mathrm{~N}_{4} \mathrm{O}_{3}, 540.2161$ ).

4.5. General Conditions for the Synthesis of (1S)-4-((1H-indol-3-yl)methyl)-1-(4-hydroxybenzyl)-1,2-dihydro -6H-pyrazino[2,1-b]quinazoline-3,6(4H)-dione (10 and 11)

In an oven-dried round-bottomed flash equipped with Teflon-coated magnetic stir bar, a rubber septum, a glass stopper, and nitrogen gas inlet compound 8 or $9(50 \mathrm{mg}, 0.092 \mathrm{mmol})$ dissolved with anhydrous $\mathrm{CH}_{2} \mathrm{Cl}_{2}(5 \mathrm{~mL})$ was added. After cooled the mixture to $-78^{\circ} \mathrm{C}, 1 \mathrm{M}$ boron trichloride in $\mathrm{CH}_{2} \mathrm{Cl}_{2}\left(190 \mu \mathrm{L}, 0.19 \mathrm{mmol}\right.$, 2eq) was added dropwise over $5 \mathrm{~min}$ at $-78^{\circ} \mathrm{C}$. After stirring for $45 \mathrm{~min}$ at $-78{ }^{\circ} \mathrm{C}$, the mixture was quenched by syringe addition of $\mathrm{CHCl}_{3} / \mathrm{MeOH}(10 / 1,10 \mathrm{~mL})$ at $-78{ }^{\circ} \mathrm{C}$ and was warmed to ambient temperature. The solvent was evaporated, and the content was purified by flash column chromatography using hexane: EtOAc (6:4) as mobile phase. Compounds $\mathbf{1 0}$ or $\mathbf{1 1}$ were obtained as pale yellow solids. Before analysis, compounds were recrystallized from methanol.

(1R,4S)-4-((1H-indol-3-yl)methyl)-1-(4-hydroxybenzyl)-1,2-dihydro-6H-pyrazino[2,1-b]quinazoline-3,6(4H)dione (10). Yield: $12.5 \mathrm{mg}, 30 \%$; $e r=36: 65 ;$ m.p.: $134-136^{\circ} \mathrm{C} ;[\alpha]_{D}^{30}=+39.5\left(\right.$ c $\left.0.034 ; \mathrm{CH}_{3} \mathrm{OH}\right) ; v_{\max }(\mathrm{KBr})$ $3427,1677,1603,1515,1468,1159,1025,998$, and $765 \mathrm{~cm}^{-1} ;{ }^{1} \mathrm{H}$ NMR (300 MHz, DMSO-d 6 ): $\delta 10.48$ (s, $1 \mathrm{H}, \mathrm{NH}-\mathrm{Trp}), 8.89(\mathrm{~d}, 1 \mathrm{H}, J=4.9 \mathrm{~Hz}, \mathrm{OH}-\mathrm{Tyr}), 8.32(\mathrm{dd}, 1 \mathrm{H}, J=8.0$ and $1.2 \mathrm{~Hz}, \mathrm{CH}), 7.81(\mathrm{dd}, 1 \mathrm{H}$, $J=7.7$ and $1.6 \mathrm{~Hz}, \mathrm{CH}), 7.61(\mathrm{~d}, J=7.9 \mathrm{~Hz}, \mathrm{CH}), 7.56(\mathrm{dd}, 1 \mathrm{H}, J=12.7$ and $7.2 \mathrm{~Hz}, \mathrm{CH}), 7.39(\mathrm{dd}, 1 \mathrm{H}$, $J=8.0$ and $5.4 \mathrm{~Hz}, \mathrm{CH}-\mathrm{Trp}), 7.34(\mathrm{dt}, 1 \mathrm{H}, J=8.1 \mathrm{~Hz}, \mathrm{CH}), 7.13(\mathrm{dd}, 1 \mathrm{H}, J=13.4$ and $6.7 \mathrm{~Hz}, \mathrm{CH}-\mathrm{Trp})$, $6.84(\mathrm{dd}, 1 \mathrm{H}, J=13.4$ and $6.7 \mathrm{~Hz}, \mathrm{CH}-\operatorname{Trp}), 6.60(\mathrm{~d}, 1 \mathrm{H}, J=3.4 \mathrm{~Hz}, \mathrm{CH}-\operatorname{Trp}), 6.58(\mathrm{dd}, 2 \mathrm{H}, J=8.5$ and $6.0 \mathrm{~Hz}, \mathrm{CH}-\mathrm{Tyr}), 6.53$ (d, 1H, J = 4.4 Hz, NH-amide), 6.46 (dd, 2H, J = 7.9 and $5.7 \mathrm{~Hz}, \mathrm{CH}-\mathrm{Tyr}), 5.44$ (dd, $1 \mathrm{H}, J=5.0$ and $\left.2.8 \mathrm{~Hz}, \mathrm{CH}^{*}-\operatorname{Trp}\right), 3.64\left(\mathrm{dd}, 1 \mathrm{H}, J=14.8\right.$ and $\left.2.7 \mathrm{~Hz}, \mathrm{CH}_{2}-\operatorname{Trp}\right), 3.56(\mathrm{dd}, 1 \mathrm{H}, J=14.9$ and $5.3 \mathrm{~Hz}), 3.26\left(\mathrm{dt}, J=13.4\right.$ and $\left.3.6 \mathrm{~Hz}, \mathrm{CH}_{2}-\mathrm{Tyr}\right), 3.03\left(\mathrm{dt}, 1 \mathrm{H}, J=8.9\right.$ and $\left.4.7 \mathrm{~Hz}, \mathrm{CH}^{*}-\mathrm{Tyr}\right), 2.67(\mathrm{dt}, 1 \mathrm{H}$, $J=13.3$ and $10.5 \mathrm{~Hz}) ;{ }^{13} \mathrm{C}$ NMR $\left(75 \mathrm{MHz}, \mathrm{CDCl}_{3}\right): \delta 168.1(\mathrm{C}=\mathrm{O}), 160.0(\mathrm{C}=\mathrm{O}), 150.5(\mathrm{C}-\mathrm{Tyr}), 146.3$ (C), 135.8 (C-Trp), $134.1(\mathrm{CH}), 129.4$ (CH-Tyr (2)), 126.7 (C-Trp), $126.6(\mathrm{CH}), 126.4(\mathrm{CH}), 126.1(\mathrm{CH})$, 
124.9 (C-Tyr), 123.7 (CH-Trp), 121.2 (CH-Trp), 119.6 (CH-Trp), 118.9 (CH-Trp), 115.0 (C-Tyr), 111.2 (CH-Trp), 108.0 (C-Trp), 56.6 ( $\mathrm{CH}^{*}$-Trp), 52.8 ( $\mathrm{CH}^{*}$-Tyr), $36.3\left(\mathrm{CH}_{2}\right.$-Tyr), $26.5\left(\mathrm{CH}_{2}\right.$-Trp); (+)-HRMS-ESI $m / z 451.1766(\mathrm{M}+\mathrm{H})^{+}, 473.1576(\mathrm{M}+\mathrm{Na})^{+}$(calculated for $\left.\mathrm{C}_{27} \mathrm{H}_{23} \mathrm{~N}_{4} \mathrm{O}_{3}, 450.1692\right)$.

(1S,4S)-4-((1H-indol-3-yl)methyl)-1-(4-hydroxybenzyl)-1,2-dihydro-6H-pyrazino[2,1-b]quinazoline-3,6(4H)dione (11). Yield: $25.7 \mathrm{mg}$, 68.7\%; er = 61:39; m.p.: $102-103{ }^{\circ} \mathrm{C} ;[\alpha]_{D}^{30}=+75.9\left(c 0.079 ; \mathrm{CH}_{3} \mathrm{OH}\right) ; v_{\max }$ (KBr) 3428, 2927, 1667, 1610, 1592, 1474, 1337, 1232, 772, and $699 \mathrm{~cm}^{-1}$; ${ }^{1} \mathrm{H}$ NMR (300 MHz, DMSO-d 6 ): $\delta 10.54$ (s, 1H, NH-Trp), 8.86 (s, 1H, OH-Tyr), $8.34(\mathrm{dd}, 1 \mathrm{H}, J=8.0$ and $1.2 \mathrm{~Hz}, \mathrm{CH}), 7.83(\mathrm{dd}, 1 \mathrm{H}$, $J=7.7$, and $1.6 \mathrm{~Hz}, \mathrm{CH}), 7.62(\mathrm{~d}, J=7.9 \mathrm{~Hz}, \mathrm{CH}), 7.56(\mathrm{dt}, 1 \mathrm{H}, J=7.6,7.6$, and $0.6 \mathrm{~Hz}, \mathrm{CH}), 7.49(\mathrm{~d}$, $1 \mathrm{H}, J=7.9 \mathrm{~Hz}, \mathrm{CH}-\mathrm{Trp}), 7.30(\mathrm{~d}, 1 \mathrm{H}, J=8.1 \mathrm{~Hz}, \mathrm{CH}), 7.20(\mathrm{~d}, 1 \mathrm{H}, J=3.3 \mathrm{~Hz}, \mathrm{NH}$-amide), $7.09(\mathrm{dt}, 1 \mathrm{H}$, $J=7.6$ and $0.6 \mathrm{~Hz}, \mathrm{CH}-\operatorname{Trp}), 6.94(\mathrm{dt}, 1 \mathrm{H}, J=7.5$ and $0.5 \mathrm{~Hz}, \mathrm{CH}-\operatorname{Trp}), 6.66(\mathrm{~d}, 1 \mathrm{H}, J=2.3 \mathrm{~Hz}, \mathrm{CH}-\operatorname{Trp})$ $6.57(\mathrm{~d}, 2 \mathrm{H}, J=5.6 \mathrm{~Hz}, \mathrm{CH}-\mathrm{Tyr}), 6.45(\mathrm{~d}, 2 \mathrm{H}, J=8.4 \mathrm{~Hz}, \mathrm{CH}-\mathrm{Tyr}), 5.37(\mathrm{dd}, 1 \mathrm{H}, J=5.2$ and $3.3 \mathrm{~Hz}$, $\mathrm{CH}^{*}$-Trp), $4.36\left(\mathrm{dt}, 1 \mathrm{H}, J=10.5\right.$ and $3.4 \mathrm{~Hz}, \mathrm{CH}^{*}$-Tyr), $3.63\left(\mathrm{dd}, 1 \mathrm{H}, J=14.8\right.$ and $\left.3.1 \mathrm{~Hz}, \mathrm{CH}_{2}-\operatorname{Trp}\right), 3.55$ $\left(\mathrm{dd}, 1 \mathrm{H}, J=14.9\right.$ and $5.4 \mathrm{~Hz}, \mathrm{CH}_{2}-\mathrm{Trp}$ ), 2.69 (dd, $J=13.4$ and $\left.3.6 \mathrm{~Hz} \mathrm{CH}_{2}-\mathrm{Tyr}\right), 0.86$ (dd, $1 \mathrm{H}, J=13.3$ and $\left.10.5 \mathrm{~Hz}, \mathrm{CH}_{2}-\mathrm{Tyr}\right) ;{ }^{13} \mathrm{C}$ NMR (75 MHz, $\left.\mathrm{CDCl}_{3}\right): \delta 165.8(\mathrm{C}=\mathrm{O}), 160.2(\mathrm{C}=\mathrm{O}), 155.8(\mathrm{C}-\mathrm{Tyr}), 150.4(\mathrm{C}=\mathrm{N})$, 146.7 (C), 135.6 (C-Trp), 134.2 (CH), 129.9 (CH-Tyr (2)), 127.4 (CH-Trp), $126.3(\mathrm{CH}), 126.2(\mathrm{CH}), 126.1$ (CH-Trp), 125.9 (C-Tyr), 123.7 (CH-Trp), 121.1 (CH-Trp), 119.5 (CH-Trp), 118.7 (CH-Trp), 114.9 (CH-Tyr (2)), 111.2 (CH-Trp), 108.0 (C-Trp), 57.2 ( $\mathrm{CH}^{*}$-Trp), $56.3\left(\mathrm{CH}^{*}\right.$-Tyr), $41.8\left(\mathrm{CH}_{2}-\mathrm{Tyr}\right), 26.1\left(\mathrm{CH}_{2}\right.$-Trp); (+)-HRMS-ESI $m / z 451.1771(\mathrm{M}+\mathrm{H})^{+}, 473.1564(\mathrm{M}+\mathrm{Na})^{+}$(calculated for $\left.\mathrm{C}_{27} \mathrm{H}_{23} \mathrm{~N}_{4} \mathrm{O}_{3}, 450.1692\right)$.

4.6. General Conditions for the Synthesis of (1S,4R)-4-((1H-indol-3-yl)methyl)-1-(4-(benzyloxy)benzyl)-8,10 -dichloro-1,2-dihydro-6H-pyrazino[2,1-b]quinazoline-3,6(4H)-dione (12)

In a closed vial 3,5-dichloro anthranilic acid (xiii, $41 \mathrm{mg}, 200 \mu \mathrm{mol}$ ), $N$-Boc-o-Bn-Tyrosine (xii, $74 \mathrm{mg}, 200 \mu \mathrm{mol})$, and triphenylphosphite $(63 \mu \mathrm{L}, 220 \mu \mathrm{mol})$ were added along with $1 \mathrm{~mL}$ of dried pyridine. The vial was heated in heating block with stirring at $55^{\circ} \mathrm{C}$ for $16-24 \mathrm{~h}$. After cooling the mixture to room temperature, D-tryptophan methyl ester hydrochloride (ii, $51 \mathrm{mg}, 200 \mu \mathrm{mol}$ ) was added, and the mixture was irradiated in the microwave at the constant temperature at $220{ }^{\circ} \mathrm{C}$ for $1.5 \mathrm{~min}$. Reaction mixtures were prepared in the same conditions and treated in parallel. After removing the solvent with toluene, the crude product was purified by flash column chromatography using hexane: EtOAc (60:40) as a mobile phase. The preparative TLC was performed using $\mathrm{CH}_{2} \mathrm{Cl}_{2}: \mathrm{Me}_{2} \mathrm{CO}$ (95:5) as mobile phase. The major compound appeared as a black spot with no fluorescence under the UV light ( $366 \mathrm{~nm})$. Compound 12 was collected as orange solids. Before analysis, compound was recrystallized from methanol. Yield: $26.2 \mathrm{mg}$, 2.2\%; er 67:33; m.p.: $233-235{ }^{\circ} \mathrm{C} ;[\alpha]_{D}^{30}=+244.44(\mathrm{c} 0.045$; $\left.\mathrm{CH}_{3} \mathrm{OH}\right) ; v_{\max }(\mathrm{KBr}) 3424,3334,2921,1681,1593,1511,1455,1247,1012,695$, and $420 \mathrm{~cm}^{-1} ;{ }^{1} \mathrm{H} \mathrm{NMR}$ $\left(300 \mathrm{MHz}, \mathrm{CDCl}_{3}\right): \delta 8.26(\mathrm{~d}, 1 \mathrm{H}, J=2.4 \mathrm{~Hz}, \mathrm{CH}), 8.09$ (br, $\left.1 \mathrm{H}, \mathrm{NH}-\mathrm{Trp}\right), 7.85(\mathrm{~d}, 1 \mathrm{H}, J=2.4 \mathrm{~Hz}, \mathrm{CH})$, $7.44(\mathrm{dd}, 5 \mathrm{H}, J=6.4$ and $2.0 \mathrm{~Hz}, \mathrm{CH}-\mathrm{Bz}), 7.39(\mathrm{~d}, 2 \mathrm{H}, J=8.2 \mathrm{~Hz}, \mathrm{CH}-\operatorname{Trp}), 7.19(\mathrm{t}, 1 \mathrm{H}, J=7.7 \mathrm{~Hz}, \mathrm{CH}-\operatorname{Trp})$, $6.96(\mathrm{t}, 1 \mathrm{H}, J=7.5 \mathrm{~Hz}, \mathrm{CH}-\operatorname{Trp}), 6.75(\mathrm{~d}, 2 \mathrm{H}, J=8.7 \mathrm{~Hz}, \mathrm{CH}-\mathrm{Tyr}), 6.62(\mathrm{~d}, 1 \mathrm{H}, J=2.3 \mathrm{~Hz}, \mathrm{CH}-\operatorname{Trp}), 6.40$ $(\mathrm{d}, 2 \mathrm{H}, J=8.5 \mathrm{~Hz}, \mathrm{CH}-\mathrm{Tyr}), 5.56\left(\mathrm{dd}, 1 \mathrm{H}, J=5.2\right.$ and 2.6, $\left.\mathrm{CH}^{*}-\operatorname{Trp}\right), 5.41(\mathrm{~s}, 1 \mathrm{H}, \mathrm{NH}$-amide), $5.06(\mathrm{~s}, 2 \mathrm{H}$, $\left.\mathrm{CH}_{2}-\mathrm{Bz}\right), 3.77\left(\mathrm{dd}, 1 \mathrm{H}, J=15.0\right.$ and $\left.2.6 \mathrm{~Hz}, \mathrm{CH}_{2}-\operatorname{Trp}\right), 3.62\left(\mathrm{dd}, 1 \mathrm{H}, J=15.6\right.$ and $\left.4.1 \mathrm{~Hz}, \mathrm{CH}_{2}-\operatorname{Trp}\right), 3.50$ (dd, $1 \mathrm{H}, J=17.5$ and $\left.4.4 \mathrm{~Hz}, \mathrm{CH}_{2}-\mathrm{Tyr}\right), 2.95\left(\mathrm{dd}, J=10.8\right.$ and $\left.3.6 \mathrm{~Hz}, \mathrm{CH}^{*}-\mathrm{Tyr}\right), 2.51(\mathrm{dd}, 1 \mathrm{H}, J=14.8$ and $\left.10.9 \mathrm{~Hz}, \mathrm{CH}_{2}-\mathrm{Tyr}\right) ;{ }^{13} \mathrm{C}$ NMR $\left(75 \mathrm{MHz}, \mathrm{CDCl}_{3}\right): \delta 168.7(\mathrm{C}=\mathrm{O}), 159.2(\mathrm{C}=\mathrm{O}), 158.0(\mathrm{C}-\mathrm{Tyr}), 152.0(\mathrm{C}=\mathrm{N})$, 142.4 (C), 136.9 (C-Bz), 136.1(C-Trp), 135.1 (CH), 133.2 (C-Cl), 132.6 (C-Cl), 129.6 (CH-Tyr (2)), 128.7 (CH-Bz (2)), 128.1 (CH-Bz), 127.4 (CH-Bz(2)), 126.9 (C-Trp), 126.6 (C-Tyr), 125.2 (CH), 123.7 (CH-Trp), 122.9 (CH-Trp), 122.4 (C), 118.9 (CH-Trp), 115.5 (CH-Tyr (2H)), 111.2 (CH-Trp), 109.4 (C-Trp), 70.1 ( $\mathrm{CH}_{2}$-Bz), 57.6 ( $\mathrm{CH}^{*}$-Trp), 53.1 ( $\mathrm{CH}^{*}$-Tyr), 36.9 ( $\mathrm{CH}_{2}$-Tyr), $27.1\left(\mathrm{CH}_{2}\right.$-Trp). (+)-HRMS-ESI $\mathrm{m} / z$ 609.1427 $(\mathrm{M}+\mathrm{H})^{+}$, (calculated for $\left.\mathrm{C}_{34} \mathrm{H}_{27} \mathrm{~N}_{4} \mathrm{O}_{3} \mathrm{Cl}_{2}, 608.1382\right)$.

\subsection{Neuroprotection Assay}

Compounds 1, 2, 4, 5, 6, 7, 8, 9, 10, 11, and 12c together with fiscalin B (3) were assayed in co-treatment with rotenone at eight concentrations per triplicate. The SH-SY5y cells (ATCC Ref.: CRL-2266) were seeded at a density of 40,000/well in a 96-well plate and were incubated in a humidified atmosphere 
at $37^{\circ} \mathrm{C}$ with $5 \% \mathrm{CO}_{2}$ for overnight. The compounds were dissolved in DMSO at the concentration of $10 \mathrm{mM}$ and the higher concentration assayed was $100 \mu \mathrm{M}$. The negative control was 1\% DMSO. After $24 \mathrm{~h}$ of co-treatment, plates were treated with MTT (3-(4,5-dimethylthiazol-2-yl)-2,5-diphenyltetrazolium bromide) at $5 \mu \mathrm{g} / \mathrm{mL}$ in Minimum Essential Medium Eagle (MEM) for $3 \mathrm{~h}$ at the standard culture condition. Then, DMSO was added to the plates to solubilizing the formazan crystal formed in viable cells and plates were put in the stirring for $5 \mathrm{~min}$ to homogenize the solution. Absorbance at $570 \mathrm{~nm}$ was measured by VICTOR Multilabel Plate Reader (PerkinElmer).

\subsection{Screening Test for Antitumor Activity}

Compounds 1, 2, 4, 5, 6, 7, 8, 10, and 11 were reconstituted in sterile DMSO to the final concentration of $60 \mathrm{mM}$, and several aliquots were made and stored at $-20{ }^{\circ} \mathrm{C}$ to avoid repeated freeze-thaw cycles. For experiments, the compounds were freshly diluted in medium to the desired concentration. Screening for tumor cell growth inhibitory activity was carried out in three human tumor cell lines (NCI-H460, BxPC3 and PANC1), with the sulforhodamine B (SRB) assay, as previously described [32]. Briefly, tumor cells were plated in 96-well plates, incubated at $37^{\circ} \mathrm{C}$ for $24 \mathrm{~h}$, and then treated for $48 \mathrm{~h}$ with 5 serial dilutions (1:2) of each compound (ranging from $25 \mu \mathrm{M}$ to $1.5625 \mu \mathrm{M}$, $150 \mu \mathrm{M}$ to $9.375 \mu \mathrm{M}$ or $200 \mu \mathrm{M}$ to $12.5 \mu \mathrm{M}$, depending on the compound and for reasons related with solubility). The effect of the vehicle solvent (DMSO) was also analyzed as a control. Cells were fixed with $10 \%$ ice-cold trichloroacetic acid, washed with water, and stained with SRB. Finally, the plates were washed with $1 \%$ acetic acid and the bound SRB was solubilized with $10 \mathrm{mM}$ Tris Base. Absorbance was measured in a microplate reader (Synergy Mx, Biotek Instruments Inc., Winooski, VT, USA) at $510 \mathrm{~nm}$. For each compound, the corresponding $\mathrm{GI}_{50}$ (concentration which inhibited $50 \%$ of net cell growth) was determined, as previously described [33].

\subsection{Testing Effect of Compounds on Non-malignant Breast Cells}

Compounds 5, 7, 10 and 11 (which presented simultaneously the best neuroprotection and antitumor effects) were tested against the non-malignant MCF-12A human breast epithelial cells. For that, cells were incubated with specific concentrations of each compound (corresponding to approximately the highest $\mathrm{GI}_{50}$ concentration obtained in the antitumor activity screening) for $48 \mathrm{~h}$, followed by removal of the compound, addition of new medium to the cells and then 5 more days in culture. At the end of the 7 days in total, the sulforhodamine B (SRB) assay was performed, as previously described [32].

\section{Conclusions}

New quinazolinone alkaloid derivatives with anti and syn stereochemistry were synthetized by combining both a one-pot microwave-assisted reaction and a multi-step approach. Interestingly, fumiquinazoline $G(\mathbf{1})$ presented a better antitumor activity in all the tumor cell lines tested, with $\mathrm{GI}_{50}$ values lower than $20 \mu \mathrm{M}$. The antitumor activity of the remaining compounds was not relevant, with $\mathrm{GI}_{50}$ values higher than $20 \mu \mathrm{M}$ in the tested cell lines. The effect of the synthesized compounds in the growth of the tested non-malignant cells was smaller than the effect on the studied tumor cells. It is worth noting that among the compounds tested, only 1, 3, 5, and 7 showed potential for neuroprotection in a PD in vitro model. This finding highlights new insights into marine natural products belonging to the proteomimetic quinazolinone alkaloids.

Supplementary Materials: The following are available online Figures S1-S57.

Author Contributions: E.S. conceived the study design. S.L. synthesized the compounds and elucidated their structure and, A.S., E.S., A.K. and M.M.M.P. analyzed the data. D.I.S.P.R. performed the LC analysis. R.F. and C.X. performed the cytotoxic studies in tumor cells and non-malignant breast cells. C.X. and M.H.V. analyzed data from the cytotoxic studies, discussed and wrote those results. S.L. and E.S. wrote the manuscript, while all authors gave significant contributions in discussion and revision. All authors agreed with the final version of the manuscript. 
Funding: This research was partially supported by the Strategic Funding UID/Multi/04423/2013 through national funds provided by FCT-Foundation for Science and Technology and European Regional Development Fund (ERDF), in the framework of the program PT2020. The authors thank to national funds provided by FCT-Foundation for Science and Technology and European Regional Development Fund (ERDF) and COMPETE under the Strategic Funding UID/Multi/04423/2013, the projects POCI-01-0145-FEDER-028736 and PTDC/MAR-BIO/4694/2014 (POCI-01-0145-FEDER-016790; 3599-PPCDT).

Acknowledgments: S.L. thanks Erasmus Mundus Action 2 (LOTUS+, LP15DF0205) for full PhD scholarship. D.I.S.P.R. thanks for her postdoctoral scholarship (NOVELMAR/BPD_2/2016-019). To Sara Cravo for technical support.

Conflicts of Interest: The authors declare no conflict of interest.

\section{References}

1. Plun-Favreau, H.; Lewis, P.A.; Hardy, J.; Martins, L.M.; Wood, N.W. Cancer and neurodegeneration: Between the devil and the deep blue sea. PLoS Genet. 2010, 6, e1001257. [CrossRef] [PubMed]

2. Klus, P.; Cirillo, D.; Botta Orfila, T.; Tartaglia, G.G. Neurodegeneration and cancer: Where the disorder prevails. Sci. Rep. 2015, 5, 15390. [CrossRef] [PubMed]

3. Resende, D.I.S.P.; Boonpothong, P.; Sousa, E.; Kijjoa, A.; Pinto, M.M.M. Chemistry of the fumiquinazolines and structurally related alkaloids. Nat. Prod. Rep. 2019, 36, 7-34. [CrossRef] [PubMed]

4. Buttachon, S.; Chandrapatya, A.; Manoch, L.; Silva, A.; Gales, L.; Bruyère, C.; Kiss, R.; Kijjoa, A. Sartorymensin, a new indole alkaloid, and new analogues of tryptoquivaline and fiscalins produced by neosartorya siamensis (kufc 6349). Tetrahedron 2012, 68, 3253-3262. [CrossRef]

5. Tamiya, H.; Ochiai, E.; Kikuchi, K.; Yahiro, M.; Toyotome, T.; Watanabe, A.; Yaguchi, T.; Kamei, K. Secondary metabolite profiles and antifungal drug susceptibility of aspergillus fumigatus and closely related species, aspergillus lentulus, aspergillus udagawae, and aspergillus viridinutans. J. Infect. Chemother. 2015, 21, 385-391. [CrossRef] [PubMed]

6. He, F.; Sun, Y.-L.; Liu, K.-S.; Zhang, X.-Y.; Qian, P.-Y.; Wang, Y.-F.; Qi, S.-H. Indole alkaloids from marine-derived fungus aspergillus sydowii scsio 00305. J. Antibiot. 2012, 65, 109-111. [CrossRef] [PubMed]

7. Takahashi, C.; Matsushita, T.; Doi, M.; Minoura, K.; Shingu, T.; Kumeda, Y.; Numata, A. Fumiquinazolines $\mathrm{a}-\mathrm{g}$, novel metabolites of a fungus separated from a pseudolabrus marine fish. J. Chem. Soc. Perkin Trans. 1 1995, 18, 2345-2353. [CrossRef]

8. Numata, A.; Takahashi, C.; Matsushita, T.; Miyamoto, T.; Kawai, K.; Usami, Y.; Matsumura, E.; Inoue, M.; Ohishi, H.; Shingu, T. Fumiquinazolines, novel metabolites of a fungus isolated from a saltfish. Tetrahedron Lett. 1992, 33, 1621-1624. [CrossRef]

9. Han, X.-X.; Xu, X.-y.; Cui, C.-b.; Gu, Q.-q. Alkaloidal compounds produced by a marine-derived fungus, aspergillus fumigatus h1-04, and their antitumor activities. Chinese J. Org. Chem. 2007, 17, 232-237.

10. Cheng, Z.; Lou, L.; Liu, D.; Li, X.; Proksch, P.; Yin, S.; Lin, W. Versiquinazolines a-k, fumiquinazoline-type alkaloids from the gorgonian-derived fungus aspergillus versicolor lzd-14-1. J. Nat. Prod. 2016, 79, $2941-2952$. [CrossRef]

11. Wong, S.M.; Musza, L.L.; Kydd, G.C.; Kullnig, R.; Gillum, A.M.; Cooper, R. Fiscalins: New sibstamce p inhibitors produced by the fungus neosartorya fischeri. Taxonomy, fermentation, structures, and biological properties. J. Antibiot. 1993, 46, 545-553. [CrossRef] [PubMed]

12. Barrow, C.J.; Sun, H.H. Spiroquinazoline, a novel substance $\mathrm{p}$ inhibitor with a new carbon skeleton, isolated from aspergillus flavipes. J. Nat. Prod. 1994, 57, 471-476. [CrossRef] [PubMed]

13. Thornton, E.; Vink, R. Treatment with a substance $\mathrm{p}$ receptor antagonist is neuroprotective in the intrastriatal 6-hydroxydopamine model of early parkinson's disease. PLoS ONE 2012, 7. [CrossRef] [PubMed]

14. Dunlop, R.A.; Cox, P.A.; Banack, S.A.; Rodgers, K.J. The non-protein amino acid bmaa is misincorporated into human proteins in place of l-serine causing protein misfolding and aggregation. PLoS ONE 2013, 8, e75376. [CrossRef] [PubMed]

15. Rodgers, K.J. Non-protein amino acids and neurodegeneration: The enemy within. Exp. Neurol. 2014, 253, 192-196. [CrossRef]

16. Long, S.; Resende, D.I.S.P.; Kijjoa, A.; Silva, A.M.S.; Pina, A.; Fernández-Marcelo, T.; Vasconcelos, M.H.; Sousa, E.; Pinto, M.M.M. Antitumor activity of quinazolinone alkaloids inspired by marine natural products. Mar. Drugs 2018, 16, 261. [CrossRef] 
17. Wang, H.; Ganesan, A. Total synthesis of the fumiquinazoline alkaloids: Solution-phase studies. J. Org. Chem. 2000, 65, 1022-1030. [CrossRef]

18. Liu, J.F.; Ye, P.; Zhang, B.; Bi, G.; Sargent, K.; Yu, L.; Yohannes, D.; Baldino, C.M. Three-component one-pot total syntheses of glyantrypine, fumiquinazoline $\mathrm{f}$, and fiscalin b promoted by microwave irradiation. J. Org. Chem. 2005, 70, 6339-6345. [CrossRef] [PubMed]

19. Okaya, S.; Okuyama, K.; Okano, K.; Tokuyama, H. Trichloroboron-promoted deprotection of phenolic benzyl ether using pentamethylbenzene as a non lewis-basic cation scavenger. In Organic Syntheses; Wiley: Hoboken, NJ, USA, 2016; Volume 93, pp. 63-74.

20. Hernández, F.; Buenadicha, F.L.; Avendao, C.; Söllhuber, M. 1-alkyl-2,4-dihydro-1h-pyrazino[2,1-b]quinazoline3,6-diones as glycine templates. Synthesis of fiscalin b. Tetrahedron Asymmetr. 2002, 12, 3387-3398. [CrossRef]

21. Campos, A.C.; Fogaça, M.V.; Sonego, A.B.; Guimarães, F.S. Cannabidiol, neuroprotection and neuropsychiatric disorders. Pharmacol. Res. 2016, 112, 119-127. [CrossRef] [PubMed]

22. Bagli, E.; Goussia, A.; Moschos, M.M.; Agnantis, N.; Kitsos, G. Natural compounds and neuroprotection: Mechanisms of action and novel delivery systems. In Vivo 2016, 30, 535-547. [PubMed]

23. Cannon, J.R.; Tapias, V.; Na, H.M.; Honick, A.S.; Drolet, R.E.; Greenamyre, J.T. A highly reproducible rotenone model of parkinson's disease. Neurobiol. Dis. 2009, 34, 279-290. [CrossRef] [PubMed]

24. Condello, S.; Currò, M.; Ferlazzo, N.; Caccamo, D.; Satriano, J.; Ientile, R. Agmatine effects on mitochondrial membrane potential andnf-kb activation protect against rotenone-induced cell damage in human neuronal-like sh-sy5y cells. J. Neurochem. 2011, 116, 67-75. [CrossRef] [PubMed]

25. Vichai, V.; Kirtikara, K. Sulforhodamine b colorimetric assay for cytotoxicity screening. Nat. protoc. 2006, 1, 1112-1116. [CrossRef]

26. Zhou, Y.; Debbab, A.; Mándi, A.; Wray, V.; Schulz, B.; Müller, W.E.G.; Kassack, M.; Lin, W.; Kurtán, T.; Proksch, P.; et al. Alkaloids from the sponge-associated fungus aspergillus sp. Eur. J. Org. Chem. 2013, 5, 894-906. [CrossRef]

27. Rodrigues, B.S.F.; Sahm, B.D.B.; Jimenez, P.C.; Pinto, F.C.L.; Mafezoli, J.; Mattos, M.C.; Rodrigues-Filho, E.; Pfenning, L.H.; Abreu, L.M.; Costa-Lotufo, L.V.; et al. Bioprospection of cytotoxic compounds in fungal strains recovered from sediments of the brazilian coast. Chem. Biodivers. 2015, 12, 432-442. [CrossRef]

28. Fujimoto, H.; Negishi, E.; Yamaguchi, K.; Nishi, N.; Yamazaki, M. Isolation of new tremorgenic metabolites from an ascomycete, corynascus setosus. Chem. Pharm. Bull. 1996, 40, 1843-1848. [CrossRef]

29. Wu, B.; Chen, G.; Liu, Z.-g.; Pei, Y. Two new alkaloids from a marine-derived fungus neosartorya fischeri. Rec. Nat. Prod. 2015, 9, 271-275.

30. Kantharaju, B.S.P.; Suresh Babu, V.V. Synthesis of fmoc-amino acid chlorides assisted by ultrasonication, a rapid approach. Int. J. Pept. Res. Ther. 2002, 9, 227-229. [CrossRef]

31. Wang, H.; Ganesan, A. Total synthesis of the quinazoline alkaloids (-)-fumiquinazoline $g$ and (-)-fiscalin $b$. J. Org. Chem. 1998, 63, 2432-2433. [CrossRef]

32. Lopes-Rodrigues, V.; Oliveira, A.; Correia-da-Silva, M.; Pinto, M.; Lima, R.T.; Sousa, E.; Vasconcelos, M.H. A novel curcumin derivative which inhibits p-glycoprotein, arrests cell cycle and induces apoptosis in multidrug resistance cells. Bioorg. Med. Chem. 2017, 25, 581-596. [CrossRef] [PubMed]

33. Kijjoa, A.; Santos, S.; Dethoup, T.; Manoch, L.; Almeida, A.P.; Vasconcelos, M.H.; Silva, A.; Gales, L.; Herz, W. Sartoryglabrins, analogs of ardeemins, from neosartorya glabra. Nat. Prod. Commun. 2011, 6, 807-812. [PubMed]

Sample Availability: Samples of the compounds 1-12 are available from the authors. 